\title{
Pre-contractual duties to inform in Early Modern Scholasticism
}

\author{
Wim Decock and Jan Hallebeek
}

\begin{abstract}
Summary
This paper seeks to highlight the early modern scholastic contribution to dealing with the issue of pre-contractual duties to inform. Bringing together different strands of thought, ranging from Aristotelian philosophy to Roman law, the 16th and 17th century scholastics developed adequate analytical tools to solve legal and moral problems arising from information disparities between contracting parties. While first looking at the different classical and medieval texts that shaped the early modern debate, this paper then goes on to give a systematic account of how the early modern scholastics dealt with duties of disclosure about both intrinsic and extrinsic defects in the merchandise. A final chapter looks at how the early modern scholastic debate was received in the Northern natural law school, before concluding that the early modern scholastics took a surprisingly negative attitude towards duties to inform.
\end{abstract}

\section{Keywords}

Early Modern Scholasticism, pre-contractual duties to inform, latent defects, 'Merchant of Rhodes', forum internum

\section{1. - Introduction}

In a recent volume, Mistake, fraud and duties to inform in European contract law, case studies taken from different countries highlight how important the pre-contractual duty of the seller to disclose the necessary information concerning his merchandise has become in most European jurisdictions. A case in point is the Dutch Civil Code (1992), which considers the information provided by the seller as determinative for the expectations of the purchaser (art. 7:17 BW), and concludes that non-conformity lies if, eventually, the

* Wim Decock, Research Fellow FWO-Vlaanderen, K.U. Leuven, Research Unit Roman Law and Legal History, Sint-Michielsstraat 6, B-3000 Leuven; wim.decock@inbox.com. Jan Hallebeek, Professor of European Legal History, VU University Amsterdam, Faculty of Law, De Boelelaan 1105, NL-1081 HV Amsterdam. The authors wish to thank Professor Margaret Hewett (University of Cape Town) for correcting the English of their text. 
object sold does not meet those expectations (art. 7:21 BW ff.) ${ }^{1}$. The seller is then considered not to have fulfilled his duties of disclosure. The editor of that volume, Ruth Sefton-Green, wonders whether the strong emphasis on the seller's duty to inform should be seen as a shift from formal validity to contractual fairness: is the contemporary law of sale characterized by a turn towards substantial, equitable standards? Is it leaving behind the rather formal, and minimal standards required in the civilian tradition ${ }^{2}$ ?

Interestingly, the volume edited by Sefton-Green also contains a chapter dealing with the historical roots of the contemporary debate on duties to inform. In this respect, Martin Josef Schermaier points out the importance of early modern scholastic doctrine and case-law for the development of our present-day concepts of mistake and duties of disclosure. Schermaier recalls how the theologians' grappling with a case known as the 'Merchant of Rhodes', as well as their more theoretical discussions about intrinsic defects in the merchandise shaped the debates ${ }^{3}$. The 'Merchant of Rhodes' questions the seller's duty to disclose his knowledge about future market conditions that are thought to be much more advantageous to the buyer than the current conditions. Contrary to the great lawyer and orator Marcus Tullius Cicero (106-43 BC) who initiated the debate in his work De officiis (On duties), the early modern scholastics conclude that the 'Merchant of Rhodes' does not have a duty of disclosure. His personal knowledge that the market-price will shortly decrease is not a defect in the merchandise itself, but a defect in the circumstances under which the sale is concluded. Hence no duty of disclosure exists. Moreover, whether intrinsic defects invariably give rise to a pre-contractual duty to inform, is in itself not easy to answer, as will appear below.

It is the aim of this paper to investigate the most vivid discussions on the duties to inform about intrinsic as well as extrinsic defects surrounding the object of sale in early modern scholasticism.

First we will highlight the classical and patristic origins of the debate in Aristotle (384-322 BC), Cicero, the Corpus Iustinianeum, and Saint Ambrose (339-397). Indispensable, too, is an overview of the seminal contributions made by Thomas Aquinas (1225-1274), Bartolus de Saxoferrato (1313-1357), Gabriel Biel (1418-1495), and Konrad Summenhart (1455-1502) in the

\footnotetext{
1 The subject has also a topical interest in view of the forthcoming debate concerning the 'Proposal for a Directive of the European Parliament on Consumer Rights' (SEC/2008/2544) and its subsequent implementation in the near future.

2 See R. Sefton-Green, General introduction, in: R. Sefton-Green (ed.), Mistake, fraud and duties to inform in European contract law, [The common core of European private law, 5], Cambridge 2005, p. 6-17. Cf. also M.J. Schermaier, Die Bestimmung des wesentlichen Irrtums von den Glossatoren bis zum BGB, [Forschungen zur neueren Privatrechtsgeschichte, 29], Wien etc. 2000 , p. $124-143$.

3 See Schermaier, Mistake, misrepresentation and precontractual duties to inform, the civil tradition, in: R. Sefton-Green (ed.), Mistake (supra, n. 2), p. 44-45 and p. 55-56.
} 
later Middle Ages. As regards early modern scholasticism itself, however, a twofold limitation has thrust itself upon us, taking into account the great number of authors participating in the early modern scholastic movement as well as the wide range of their treatments of duties to inform.

For the first half of the sixteenth century we have focussed on the philosopher John Mair (ca. 1469-1550), who taught in Paris, and the Dominican theologians Francisco de Vitoria (1483/1492-1546), and Domingo de Soto (1494-1560), who dominated the debate in Salamanca. To broaden the background, we have also included the Franciscan friar Antonio de Córdoba (1485-1578), Juan de Medina (1490-1546), who was a dissonant voice from Alcalá de Henares, the canonist and bishop Diego de Covarruvias y Leyva (1512-1577), and the Augustinian friar Pedro de Aragón (ca. 1545-1592). For the end of the sixteenth century and the beginning of the seventeenth, as the Jesuits take the leading role in developing early modern scholastic moral and legal thought, we have selected Gregorio de Valencia (1549-1603), Luís de Molina (1535-1600), Lenaert Leys (Leonardus Lessius) (1554-1623), and Juan de Lugo (1583-1660) ${ }^{4}$.

As to the contents of the debate, we have restricted ourselves to one specific intrinsic defect, namely the defect - known to the seller - in the quality of the merchandise, and to one specific extrinsic defect - also known to the seller-, namely the circumstance that the market-price may shortly be expected to decrease.

\section{2. - The Classical and Medieval heritage}

\section{1. - Greek, Roman, and patristic sources}

Typically, the early modern scholastics drew on a number of intellectual traditions in order to address the problem of pre-contractual duties to inform. Although they often express their thoughts as an explicit commentary on Thomas Aquinas, it is obvious that through their intellectual father's thinking they were first and foremost imbued with Aristotelian notions of justice in exchange and voluntariness as one of the foundations of moral action.

In Book III of his Nichomachean Ethics Aristotle develops the argument that man is responsible for his acts only to the extent that he acts freely and in the absence of ignorance or compulsion. Accordingly, mistake and duress undermine free human action. Whatever is done by virtue of ignorance is not voluntary. Moreover, a person can be blamed or praised only for actions that he performs voluntarily. So a man is not responsible for his actions if he

\footnotetext{
${ }^{4}$ Succinct bio-bibliographical information on these as well as other scholastic authors (period from ca. 1500 to 1800) is now available on Jacob Schmutz's (Université Paris-IV Sorbonne) website: www.scholasticon.fr.
} 
is carried away by a hurricane. But what about a captain who throws his goods overboard in a storm in order to save the crew? At the moment of action, he definitely wishes to jettison cargo, but he would definitely not have wished to do so in the abstract. So there is also a category of actions that are mixed 5 . Aristotle seems to conclude that such forced acts are nevertheless voluntary acts. Thomas Aquinas carries this further and in his Summa Theologiae says that the captain acted voluntarily simpliciter, that is, here and now, and involuntarily secundum quid, that is, as such apart from the actual circumstances $^{6}$.

Aristotle added some further grist to the mill of future discussions on voluntary consent in book V of his Nichomachean Ethics, where he asserts that 'no one is treated unjustly, if he consents'. It is echoed in Roman law, for instance in D. $47,10,1,5$, where it is stated that 'that is no injury which is done to one who consents (nulla iniuria est quae in volentem fiat)' and in D. 39,3,9,1 (nullam enim potest videri iniuriam accipere qui semel voluit). Yet it would be naive to jump to the conclusion that Aristotle laid the foundations of the modern principle of contract law to the effect that will is a sufficient condition of justice. In the same book V we find Aristotle developing a theory of justice in voluntary and involuntary transactions, which indeed stresses the need for equilibrium (contrapassum). Among voluntary transactions he puts contracts, among involuntary actions what today pertains to the law of delict or to criminal law. In his Summa Theologiae, Aquinas denotes justice in voluntary transactions as commutative justice (iustitia commutativa) and uses aequalitas to render the Greek word for equilibrium in Latin. In this manner, the foundations of the scholastic doctrine on justice in contractual exchange were laid. The Aristotelian-Thomistic principle of justice implies that in case of defective merchandise the selling price should correspond to the defective quality of the object sold.

A second authoritative tradition is that of Roman law, certainly in its Medieval form. It should be noted, first, that the Corpus Iustinianeum contains a case which, when combined with considerations of Aristotelian equality and justice in exchange, would give rise to the doctrine of the just price and the doctrine of laesio enormis as found in the writing of the scholastics and canonists of the later Middle Ages. In C. 4,44,2 a seller suffers prejudice because his real estate is sold for less than half of the normal price. The buyer is then expected to pay the rest of the price, or to make restitution of the

\footnotetext{
5 See Aristotle, Ethica Nicomachea, 3, 1, 1110a4-19. We consulted the following edition: Aristotelis Ethica Nicomachea, recognovit brevique adnotatione critica instruxit I. Bywater, [Scriptorum classicorum bibliotheca Oxoniensis], Oxonii $1970^{15}$ [=1894], p. 40-41.

${ }_{6}$ Thomas Aquinas, Summa Theologiae, IaIIae, quaest. 6, art. 6, resp. We consulted the following edition: Prima Secundae Summae Theologiae a quaestione 1 ad quaestionem 70, in: Thomae Aquinatis opera omnia iussu impensaque Leonis XIII edita, tom. 6, Romae 1891, p. 61.

7 Cf. Aristotle, Ethica Nicomachea (supra, n. 5), 5, 11, 1138a12, p. 112.
} 
estate. The notion of just price (pretium justum) is mentioned in this connection not to protect a buyer, however, but to protect a poor seller ${ }^{8}$. Moreover, the buyer is liable not for simple but for extreme prejudice.

In the Middle Ages this passage from the Codex was applied more generally to all types of cases where either a seller or a buyer was deceived. Thus was born a general doctrine holding that deceit for more than half of the just price amounted to great prejudice (laesio enormis) ${ }^{9}$. While the civilians insisted that an action on laesio enormis could only lie if the price exceeded more than half of the just price ${ }^{10}$, the canonists and early modern scholastics considered any deviation from the just price as a sin against the virtue of justice ${ }^{11}$. Even though from the civilians' point of view a buyer could not always justify rescission on the basis of C. $4,44,2$, there was still the possibility to sue the seller on account of latent defects. At least if the seller could be assumed to have known or to have had a duty to know about these latent defects. According to Roman law, this knowledge in the pre-contractual stage would have resulted in full contractual liability (under the actio empti), that means for all damages including consequential losses ${ }^{12}$.

Yet another technical distinction, constructed on the basis of Roman legal sources, needs mentioning here: the distinction between two kinds of deceit, viz. dolus causam dans contractui and dolus incidens in contractum. This distinction was developed through a confusion, once more of the Corpus Iustinianeum and Aristotelian philosophical terminology in the Middle Ages on the basis of D. 4,3,7pr. It was developed by the Bolognese glossators and

8 That Justinian did not mean to establish a general doctrine of just pricing is argued, also with reference to the historical context, in R. Zimmermann, The law of obligations, Roman foundations of the civilian tradition, Cape Town 1990, p. 259-268.

9 See J.W. Baldwin, The Medieval theories of the just price: romanists, canonists and theologians in the twelfth and thirteenth centuries, Transactions of the American Philosophical Society, 49 (1959), p. 3-92; and K.S. Kahn, Roman and Frankish origins of the just price of medieval Roman and Canon Law, New York 1973.

${ }_{10}$ See the gloss Iudicis ad C. 4,44,2.

11 The just price should not be considered a static or objective standard, however, as Johann Gottlieb Heineccius (1681-1741) wrongly thought the scholastics held it to be. In the early modern scholastic conception, the just price is simply the market price under competitive circumstances, or the price set by the public authorities taking into account market factors like scarcity and abundance; cf. O. Langholm, The legacy of scholasticism in economic thought: antecedents of choice and power, Cambridge 1998, p. 77-99.

12 See D. 19,1,13pr. and D. 19,1,6,4. The early modern scholastics, however, pay more attention to the aedilitian remedies of Roman law, which could only be used during a limited time for rescission (actio redhibitoria) or price reduction (actio quanti minoris), not for all damages. This may be due to the fact that in his Quodl. II q. 5 art. 2, Thomas Aquinas speaks about the provisions of civil law in case of an animal morbosum. Cf. Quaestiones de quolibet, in: Opera omnia iussu Leonis XIII edita, cura et studio fratrum praedicatorum, tom. 25, vol. 2, ParisiisRomae 1996, p. 228-229. The word morbosus is reminiscent of the morbus of animals, literally mentioned in the texts of the aedilitian edicts. See D. 21,1,1,1 and D. 21,1,38. 
we find it in Azo $(\dagger 1220)^{13}$ as well as in the Ordinary Gloss of Accursius (ca.1182-1263). When the buyer would not have bought the object at all if he had known of the defect, there was dolus dans causam contractui. He was deceived in the essentialia of the sale. As a consequence such a sale was void. When the buyer, however, still would have bought the object, when he had known the defect, albeit for a lower price, there was dolus incidens. He was deceived in the accidentalia of the sale. The contract was valid, although the buyer could claim damages ${ }^{14}$.

A third strain of thought, in addition to the Aristotelian and the Roman law tradition, which runs through the early modern scholastics' debates, stems from De officiis, a work of Cicero on moral philosophy, written around 44 B.C. Certainly, with regard to the discussions on the duty to disclose information about external circumstances to a contract, Cicero's De officiis proved to be vital in that it contained the case of the 'Merchant of Rhodes' 15 . The story goes as follows. An honest merchant is shipping grain from Alexandria to the island of Rhodes, where prices have raced up and people are dying from starvation. At the same time, he knows that many more grain merchants are setting forth to Rhodes. They will be arriving there in the near future. The qualm of conscience he faces is whether or not he is morally obliged to disclose his information about the additional relief which is on its way. If he does, he fears that he will fail to make huge profits. If he does not, the wretched buyer will suffer damage ${ }^{16}$. In fact, this case is set against the background of Cicero's larger, and typically Stoic discussion about the wrongfully perceived antithesis between the morally right (honestum) and the expedient (utile).

Cicero tackles the problem of the 'Merchant of Rhodes' as well as duties to inform about intrinsic defects in an attempt to show that it is a mistake to believe that dishonesty and morally irresponsible behaviour are the necessary prerequisites for material success. In his view, honesty leads to honour

13 See, e.g., Azo, Summa Codicis, ad C. 4,49, Lugduni 1559, f. 111va, num. 21-23.

${ }^{14}$ Further literature: Zimmermann, The law of obligations (supra, n. 8), p. 670-677; A. Wacke, Circumscribere, gerechter Preis und die Arten der List (Dolus bonus und dolus malus, dolus causam dans und dolus incidens) unter besonderer Berücksichtigung der SSS 138 Abs. II und 123 BGB, Zeitschrift der Savigny Stiftung, Rom. Abt., 94 (1977), p. 184-246.

15 Cicero's discussion of the 'Merchant of Rhodes' was studied against the background of Roman sales law by D. Waibel, Aufstieg und 'Fall' des alexandrinischen Getreidehändlers, Ausgewählte Informationsprobleme beim Kauf von Cicero bis Savigny, in: M. Ascheri e.a. (eds.), Ins Wasser geworfen und Ozeane durchquert, Festschrift für Knut Wolfgang Nörr, Köln-Weimar-Wien 2003, p. 1057-1074. Contrary to what the title of this contribution might suggest, it does not contain a single reference to the vast reception of the case in the late Medieval, Renaissance, or early modern period. As to its reception in humanist authors like Caspar Barlaeus (1584-1648) in the Netherlands, see W. Decock, Leonardus Lessius en de koopman van Rhodos, Een schakelpunt in het denken over economie en ethiek, De Zeventiende Eeuw, 22 (2006), p. 247-261.

${ }_{16}$ Cicero, De officiis, 3, 12, 50. We consulted the following edition: Cicéron, Les devoirs, livres II et III, texte établi et traduit par M. Testard, [Collection des Universités de France], Paris 1970 , p. 96. 
(honor), with honour being the very basis of utility (utilitas). But you cannot lead an honourable life unless you take into account other people's interests, and are perceived to do so. After all, even on an etymological level, there is an unmistakable connection between the Latin words for moral decency (honestas), and reputation (honor). Therefore, even if the 'Merchant of Rhodes' is aiming at expediency, he should not think that he will be better off by availing himself of his private information to the detriment of his fellow human beings. For then his reputation will be ruined.

Thus Cicero makes the case for a very large duty of disclosure. He takes the view of the Stoic philosopher Antipater of Sion that the buyer should not remain uninformed about any detail the seller knows, because the seller was born in this world as a member of a social community which naturally binds all people together (inter homines natura coniuncta societas), and the interests of whom he should serve and equate with his own interest ${ }^{17}$. On the other hand, Cicero is said - in the Thomistic tradition - to believe with Diogenes of Babylonia that it would be absurd for a seller to think he is bound to send a messenger through the streets publicly crying out that the house he is selling is unhealthy ${ }^{18}$. In fact, Cicero expressly disagrees with Diogenes of Babylonia, when he finds him defending the case of a very thin morality, namely asserting that a seller is allowed to look after his own interest as long as positive law does not expressly urge him to disclose his information to the buyer ${ }^{19}$. According to Diogenes, the seller can abide by the market price, although he is not allowed to misrepresent market circumstances. Moreover, Diogenes makes a distinction between expressly concealing information that could be important for the other party to the contract, and simply keeping silent about his information ${ }^{20}$.

Yet Cicero, considering expediency and morality to be synonymous, demanded higher moral standards from businessmen. Not only was expressly trying to conceal information, let alone lying, morally objectionable in Cicero's eyes, but also merely keeping silent about defects ${ }^{21}$. For would not the 'Merchant of Rhodes', would not a proprietor who does not disclose his information about the unhealthy state of the house he is trying to sell be considered a man who is sly, underhand and grown old in fraud, Cicero asks? And is not this ill reputation contrary to expediency ${ }^{22}$ ?

In his Christian adaptation of Cicero's De officiis, St. Ambrose of Milan, writing in approximately 388 A.D., points out the weaknesses in his pagan predecessor's argument, while at the same time strengthening his case for a

${ }_{17}$ Cicero, De officiis, 3, 12, 53, (ed. Testard, supra, n. 16), p. 98.

${ }_{18}$ Cicero, De officiis, 3, 13, 55, (ed. Testard, supra, n. 16), p. 99.

19 Cicero, De officiis, 3, 12, 51, (ed. Testard, supra, n. 16), p. 97.

${ }^{20}$ Cicero, De officiis, 3, 13, 57, (ed. Testard, supra, n. 16), p. 99.

${ }^{21}$ Cicero, De officiis, 3, 14, 58, (ed. Testard, supra, n. 16), p. 100.

22 Cicero, De officiis, 3, 13, 57, (ed. Testard, supra, n. 16), p. 100. 
very large duty of disclosure of both internal and external circumstances to a purchase-sale contract ${ }^{23}$. Referring to Plato's imaginative story, known as 'The ring of Gyges'24, about the effects of invisibility on moral behaviour, Ambrose lays bare the shame culture underlying pagan ethics. What is the force of Cicero's plea for the identification of expediency and honesty, if one's honour cannot be tainted by immoral behaviour, as is the case with Gyges, who is rendered invisible by the ring he wears? Christianity has much more argumentative force, says Ambrose. For a Christian is still left with the inner voice of conscience which can condemn him for acting immorally regardless of whether the shameful act was seen by other persons or not. A Christian is his own accuser ${ }^{25}$. In fact, what we are witnessing here is the birth of conscience. It is the development of this conscience, conceived of as a court, the mechanisms and extent of which we will be able to observe in the works of the early modern scholastics.

Nevertheless, as a rule the scholastics reacted fiercely against Ambrose's diatribe against speculative commercial activities. In a highly rhetorical piece of writing, Ambrose depicted and indeed destroyed the image of businessmen who prided themselves on their unflagging zeal and prudence in making large fortunes through speculation ${ }^{26}$. In addition, Ambrose mentions, though tongue in cheek, that these businessmen claim support for their speculative activities from the Bible, and from Genesis 40 in particular, where Joseph is said to have bought up all grain stocks in Egypt on account of his knowledge of future shortages. Ambrose, however, sharply refutes those arguments, saying that Joseph had for his part not intended to make money through speculation, but to ensure sustained provisions of grain to the whole population. Moreover, Ambrose holds that profits made through speculation always lead to the detriment of the commonwealth, calling this so-called 'art of

${ }^{23}$ An interesting, and comparative study of Cicero's and Ambrose's De officiis is M. Becker, Die Kardinaltugenden bei Cicero und Ambrosius: De officiis, [Chrêsis, Die Methode der Kirchenväter im Umgang mit der antiken Kultur, 4], Basel 1994, esp. p. 213-227 on the third book.

${ }^{24}$ See Plato, Republic, 2, 3, 359b-360d. We consulted the following edition: Platon, La république, livres I-III, texte établi et traduit par E. Chambry avec introduction d'A. Diès, in: Platon, Oeuvres complètes, [Collection des Universités de France], Paris 1947, tom. 6, p. 52 53.

${ }_{25}$ Ambrose, De officiis, 3, 5, 29, in: Ambrose, Les devoirs, livres II et III, texte établi et traduit par M. Testard, [Collection des Universités de France], Paris 1992, p. 93-94: 'Nihil agit sapiens nisi quod cum sinceritate, sine fraude sit; neque quidquam facit in quo se crimine quoquam obliget etiamsi latere possit. Sibi enim est reus priusquam ceteris nec tam pudenda apud eum publicatio flagitii quam conscientia est'.

${ }_{26}$ In Ambrose, De officiis, 3, 6, 39, (ed. Testard, supra, n. 25), p. 99, we find the businessmen claiming the following against their detractors: 'Num industria in crimen vocatur? Num diligentia reprehenditur? Num providentia vituperatur?'. This is exactly the kind of argument put forward by the scholastics of the early modern period to defend the Merchant of Rhodes' right not to disclose information about future market conditions. 
profit-making through speculation and industry' nothing less than robbery and theft ${ }^{27}$.

To conclude, in sharing Cicero's bias against trade and commerce, Ambrose sharply opposes the business man's wisdom of the flesh to divine wisdom. Against the background of the renaissance of cities and commerce from the 12 th century onwards, his younger Christian colleagues would be urged to take a more nuanced view.

\section{2. - Late Medieval discussions from Aquinas to Summenhart}

\subsection{1. - Intrinsic defects}

There is hardly any authoritative work with stronger influence on the early modern scholastic tradition than Thomas Aquinas' Summa Theologiae, which in the early sixteenth century replaced the Sententiae of Peter Lombard (ca. 1100-1160) as a textbook for theology students throughout Europe. In the part of this magnum opus mainly dealing with moral theological and legal issues, and known as the Secunda secundae, Aquinas tackles the question of defects in the quality of the merchandise (quaestio 77, article 3). This was probably written between 1270 and 1272 . As stated above, intrinsic defects in the merchandise are those defects which by themselves are determinative for the just price. We will focus on one of these, namely defects in the quality (qualitas), and the question of whether or not the seller has a duty to disclose them. These defects - often specifically denoted in Latin by the term vitia at least from Vitoria's commentary on Aquinas onwards - should be distinguished from defects in the substance (species), on the one hand (namely those concerning the essence of the object sold) and defects in the quantity (quantitas), on the other (namely those concerning the number, weight or measure of the merchandise $)^{28}$. Regarding the question whether or not the seller is obliged to disclose the defects in the quality, various ideas, handed down from the past, were relevant. First, Aquinas adopts a distinction deriving from Roman law (D. 21,1,14,10) between latent and patent defects. In the case of visible, apparent defects (vitia manifesta), such as a horse with one eye, there is no need to mention it to the buyer as long as the selling price is in conformity with the defective merchandise - a conclusion which no doubt derives from Aristotle's idea of equality in exchange. In the case of latent defects (vitia occulta), a duty of disclosure only exists if they cause harm (damnum) - as when the buyer pays too high a price - or if they cause risk (periculum) - as when the house sold is falling into ruins, the horse is lame

27 Ambrose, De officiis, 3, 6, 44, (ed. Testard, supra, n. 25), p. 102.

28 Thomas Aquinas, Summa Theologiae, IIaIIae, quaest. 77, art. 2, concl. We consulted the following edition: Secunda Secundae Summae Theologiae a quaestione 57 ad quaestionem 122, in: Thomae Aquinatis Opera omnia iussu impensaque Leonis XIII edita, tom. 9, Romae 1897, p. $150-151$. 
or food is contaminated. Otherwise the seller may keep silent about the latent defects as long as the price is in accordance with the defective state of the thing sold. This idea may be prompted by the fact that buyers are familiar with the market prices and can perceive a reduced price as a quality indica$\operatorname{tor}^{29}$ :

I reply that it is always illicit to cause harm or risk to another person, although it is not necessary for a human being always to provide his fellow man with help and advice to the latter's advantage. That is only necessary in some specific situations, for example when the other is submitted to his care, or when there is no other person who can help him. Now, the seller who offers something for sale, causes the buyer harm or risk by the mere fact that he offers him something defective, if that defect can result in harm or danger. The seller causes harm when the thing offered for sale actually needs to be priced much lower on account of its defect, but he does not reduce the price. The seller causes risk if on account of its defect the use of the thing is impossible or dangerous, for example, when someone sells a lame horse as if it were fleet of foot, or a dilapidated house as if it were solid, or contaminated food as if it were good. So whenever such defects are latent and the seller does not disclose them, the sale will be illicit and fraudulent, and he will be obliged to pay damages. If, however, a defect is apparent, for instance when a horse has only one eye, or if a thing is still likely to be useful to other persons though it is not any longer to the seller himself, no duty of disclosure exists provided that the seller reduces the price in accordance with the seriousness of the defect. For otherwise the buyer would wish the price to be reduced further than is necessary. Consequently, it is allowed for a seller to secure his own protection by not disclosing the defect in his merchandise.

Aquinas had dealt with a similar question a few years earlier, probably in the Advent of 1269, in quodlibetal question II, quaest. 5, art. 2. Yet there

29 See Thomas Aquinas, IIaIIae (ed. Leonina, supra, n. 28), quaest. 77, art. 3, concl., p. 152: 'Respondeo dicendum quod dare alicui occasionem periculi vel damni semper est illicitum: quamvis non sit necessarium quod homo alteri semper det auxilium vel consilium pertinens ad eius qualemcumque promotionem, sed hoc solum est necessarium in aliquo casu determinato, puta cum alius eius curae subdatur, vel cum non potest ei per alium subvenire. Venditor autem, qui rem vendendam proponit, ex hoc ipso dat emptori damni vel periculi occasionem quod rem vitiosam ei offert, si ex eius vitio damnum vel periculum incurrere possit: damnum quidem, si propter huiusmodi vitium res quae vendenda proponitur minoris sit pretii, ipse vero propter huiusmodi vitium nihil de pretio subtrahat; periculum autem, puta si propter huiusmodi vitium usus rei reddatur impeditus vel noxius, puta si aliquis alicui vendat equum claudicantem pro veloci, vel ruinosam domum pro firma, vel cibum sive venenosum pro bono. Unde si huiusmodi vitia sint occulta et ipse non detegat, erit illicita et dolosa venditio, et tenetur venditor ad damni recompensationem. Si vero vitium sit manifestum, puta cum equus est monoculus; vel cum usus rei, etsi non competat venditori, potest tamen esse conveniens aliis; et si ipse propter huiusmodi vitium subtrahat quantum oportet de pretio: non tenetur ad manifestandum vitium rei. Quia forte propter huiusmodi vitium emptor vellet plus subtrahi de pretio quam esset substrahendum. Unde potest licite venditor indemnitati suae consulere, vitium rei reticendo'. 
the distinction between latent and patent defects is lacking. Nor is the possible danger for the buyer mentioned. Aquinas merely states that defects do not have to be disclosed as long as the price corresponds to the defective nature of the thing sold.

Two late Medieval theologians, steeped in the Thomistic tradition, also exercised a considerable influence on the doctrines of the early modern scholastics. Both taught theology at the recently founded University of Tübingen (1477).

The first is Gabriel Biel, who in his commentary on the Sentences of Peter Lombard, first rephrases the teachings of Aquinas from the Summa Theologiae. He writes that in the case of latent defects it is allowed to conceal them, if that does not cause the buyer to suffer injury or run risks. The reason is that, otherwise, the buyer wants to pay even less than the just price, and, as Aquinas states, the seller may justly secure his own protection. Biel then continues and refers to the following distinction. Firstly, it is not allowed to keep silent about defects if the buyer would not have bought at all, had he known of these defects. For another, a seller is allowed to conceal defects if the buyer would have bought the merchandise regardless, albeit it for a lower price, as long as the seller adjusts the selling-price to the defective quality ${ }^{30}$. Although Biel ascribes this distinction merely to the canonist Abbas Panormitanus (1386-1445) ${ }^{31}$ and the Italian Franciscan Angelo Carletti de Chivasso (ca. $1414-1495)^{32}$, it is definitely reminiscent of the Glossators' subdivision of deceit into dolus causam dans and dolus incidens.

The other Tübingen professor of theology is Konrad Summenhart, usually referred to as Conradus. Unlike Gabriel Biel, he is frequently quoted in the teachings of the early modern scholastics on qualitative defects. In his influential work De contractibus licitis atque illicitis, Summenhart deals extensively with the sale of defective merchandise and the seller's obligation to inform the buyer. He holds that a seller in good faith is not liable for any of the intrinsic defects, namely those in the substance, the quality and the quantity. His ignorance should not imply a gross mistake (crassa), however, and it is not allowed to deliberately sell something defective. In this context, Summenhart draws a distinction, resembling that of Biel just mentioned, and corresponding with the difference between the Roman actio redhibitoria and actio quanti minoris, viz. between the situation where the buyer wants to restore the object in exchange for the price upon noticing the defect, and the event in which he merely claims reduction of the price. In the latter case he was willing to

${ }^{30}$ G. Biel, Collectorium circa quattuor libros Sententiarum, lib. 4, pars 2 (dist. 15-22), (ed. W. Werbeck / U. Hofmann), Tübingen 1977, dist. 15, quaest. 10, art. 3, dub. 1, p. 206-207. ${ }^{31}$ Abbas Panormitanus (Nicolaus de Tudeschis), Commentaria in tertium decretalium librum, [Opera Omnia, tom. 6], ad X. 3, 19, 4,Venetiis 1588, f. 141ra, num. 2.

32 Angelo Carletti de Chivasso, Summa angelica de casibus conscientiae, [s.l.] 1520, s.v. emptio et venditio, f. $65 \mathrm{rb}-65 \mathrm{va}, \mathrm{n} .8$. 
buy the object, albeit for a lower price, even when he was aware of the defect. Again this distinction is probably derived from the Medieval Roman law distinction between dolus causam dans and dolus incidens - technical vocabulary Summenhart explicitly uses in the rest of his treatment. If the buyer had been willing to pay a lower price which corresponds to the extent of the defect, the seller is obliged to restore the balance. If the buyer, however, would by no means have bought the object, he is erring and not consenting to the contract. In that case, no matter what happens according to the forum externum, in the forum animae the full price must be given back ${ }^{33}$. Moreover, if the seller suspects that the buyer does not know of the defect, it does not matter, according to Summenhart, whether the defect is apparent or latent. A defect can be apparent, that is recognizable, and yet the seller may have to assume that for the specific buyer it is hidden anyway. Hence, defects apparent in that way are still to be considered as latent ${ }^{34}$.

\subsection{2. - Extrinsic defects}

Although Aquinas was not addressing the question of pre-contractual duties to inform about circumstances extrinsic to a contract as such, he made a vital contribution to root out such obligations. He does so within the context of his discussion of the duty of disclosure of intrinsic defects - which has been expounded above. Those who hold that a seller is under no obligation to inform about the defects of the merchandise argue, amongst other things, that there is a similarity between the non-obligation of the 'Merchant of Rhodes' to tell about the future abundance in goods, and the non-obligation of a seller to disclose his information about latent defects ${ }^{35}$.

Importantly, Aquinas rejects this analogy established by his opponents between the case of the 'Merchant of Rhodes' and the case of intrinsic, latent defects in the goods sold. Consequently, he denies that from the non-obligation of disclosure in the case of the 'Merchant of Rhodes' one can infer the same principle of non-obligation in the case of latent defects. For the first time, then, though it is not expressed in the abstract, the distinction between extrinsic and intrinsic qualities of a purchase-sale contract is brought to bear upon the question of duties of disclosure ${ }^{36}$ :

33 Conradus Summenhart, Septipertitum opus de contractibus, Augustae Vindelicorum 1515, tract. 3, quaest. 54, par. Prima conclusio [without foliation].

${ }^{34}$ Summenhart, De contractibus (supra, n. 33), tract. 3, quaest. 54, par. Corollarium primum [without foliation].

35 Thomas Aquinas, Summa Theologiae (ed. Leonina, supra, n. 29), IIaIIae, quaest. 77, art. 3, arg. 4, p. 152: 'Praeterea, si aliquis teneatur dicere defectum rei venditae, hoc non est nisi ut minuatur de pretio. Sed quandoque diminueretur de pretio etiam sine vitio rei venditae, propter aliquid aliud, puta si venditor deferens triticum ad locum ubi est carestia frumenti, sciat multos posse venire qui deferant; quod si sciretur ab ementibus, minus pretium darent. Huiusmodi autem non oportet dicere venditorem, ut videtur. Ergo, pari ratione, nec vitia rei venditae'.

${ }^{36}$ Thomas Aquinas, Summa Theologiae (ed. Leonina, supra, n. 29), IIaIlae, quaest. 77, art. 3, 
A defect in something immediately causes that thing to be priced lower now than it seems to be worth. In our case, however, the grain is expected to be priced lower in the future because of the arrival - which is unknown to the buyers - of additional merchants. Hence, a seller demanding the price which he finds in the market does not seem to act against justice if he does not disclose his information about the future. Still, if he were to do so, or if he lowered his price, it would be exceedingly virtuous on his part, although he does not seem to be under an obligation as a matter of justice to do so.

Unfortunately, Thomas Aquinas did not elaborate on this short but highly influential statement. In any event, his commentators invariably considered him to be the chief scholastic authority to have defended the 'Merchant of Rhodes' non-duty of disclosure. This did not settle the dispute, however.

The authoritative foundations for disagreement were laid in the law faculty, in particular, by none less than Bartolus de Saxoferrato. In his commentary on D. 19,1,39, which invalidates a seller's attempt to discharge himself from liability for eviction of servitudes attached to the land he sells, he introduces a problem that is not wholly identical to Cicero's 'Merchant of Rhodes', but still touches upon a similar question: namely insider information. Assume that the public authorities will decree to lower the official price of a certain commodity, and you as a particular vendor, familiar with the administration, know about this future decree through insider information. Are you liable for the damage which a buyer incurs because you do not disclose your insider information to him? Bartolus definitely thinks you are. A seller is under an obligation to share his insider information with the buyer, according to the most eminent amongst the commentators, because not so doing amounts to fraud (circumventio) ${ }^{37}$.

In order to support his view, Bartolus refers to the gloss Contra ad D. 1,3,29, which assimilates acts that go against the spirit of the law (in fraudem legis) to acts that go against the letter of the law (contra legem). Accursius, however, did not address the question of the 'Merchant of Rhodes'. In his commentary on this famous passage, and by making reference to Guilelmus de Cuneo (ca. 1270-1335), Bartolus recounts the story of a seller from the leading classes

ad 4, p. 152-153: 'Ad quartum dicendum quod vitium rei facit rem in praesenti esse minoris valoris quam videatur, sed in casu praemisso, in futurum res expectatur esse minoris valoris per superventum negotiatorum, qui ab ementibus ignoratur. Unde venditor qui vendit rem secundum pretium quod invenit, non videtur contra iustitiam facere si quod futurum est non exponat. Si tamen exponeret, vel de pretio subtraheret, abundantioris esset virtutis, quamvis ad hoc non videatur teneri ex iustitiae debito'.

37 Bartolus a Saxoferrato, In secundam Digesti veteris partem, ad D. 19,1,39, Venetiis 1570: 'Ordinationem qui sciens factam per superiorem quod aliqua res vendatur minori pretio solito, si vendit pro maiori pretio quam fuerit ordinatum, tenetur. (...) Quia videtur facere causa circumveniendi eo ipso, quod scit. (...) Vendidit tibi frumentum pro maiori pretio nec certioraverit te. Certe videtur teneri ad interesse, et ita glos. sensit in l. Contra legem facit, tit. de legibus' [D. 1,3,29]. 
who does not disclose his insider information about the future change in the official price of grain as an instance of behaviour that goes against the prohibition to act in contravention of the spirit of the law. Bartolus's opinion is not just ephemeral. One century later, it lives on word for word in the Singularia of the jurist and merchant Ludovicus Pontanus Romanus (1409$1439)^{38}$.

With the greatest authorities in the law and theology faculties, respectively, diverging on the duty to inform about future market conditions, it should not come as a surprise that by the end of the 15th century, we find the theological tradition split in two.

In his commentary on the Sentences, Biel bases himself on Aquinas and simply states that as a matter of justice a merchant is neither under an obligation to reduce the price of the thing sold nor under a duty to inform. He motivates this conclusion by pointing out the infirm and uncertain character of the 'Merchant of Rhodes' knowledge about the future: all future events are contingent and unpredictable ${ }^{39}$. This is an important argument, preparing some of the early modern scholastics' view of business as an aleatoric game in which making profits on the basis of a dominant knowledge position is thought to be allowed precisely to the extent that a merchant benefiting from a dominant knowledge position actually can turn out to be mistaken.

No less influential, but far more subtle and extended was the discussion of the 'Merchant of Rhodes' in yet another late Medieval theologian from Tübingen. In his treatise on contracts, Konrad Summenhart is the first among the theologians to take and defend the view that there exists a duty of disclosure, or at least a duty to reduce the price. The bottom line of his argument is that an imminent future supply of goods already influences the current market price in the present, and that a buyer who is not informed does not voluntarily consent to the purchase-sale agreement but rather does so on account of error $^{40}$. Moreover, a seller who thinks, or is to be expected to think, that the price of his goods will sink in the near future actually knows that the monetary value or price of his goods does not correspond any more to its real value. Hence, he deceives the buyer either on purpose or on account of crass ignorance. In Summenhart's view, the uncertainty surrounding the imminent abundance explains, however, why the seller can still ask 9 if the current price is 10 and the future price will be 8 .

${ }^{38}$ Ludovicus Pontanus Romanus, Singularia, Lugduni 1541, [s.f.], num. 282: 'Numquid si sum magnus mercator et sciam in consilio de ordine dato quod cras minus valebit frumentum. Et ego vendidi non notificando emptoribus de ordinatione predicta. Dicendum quod contrahentes possunt agere contra me ad interesse suum'.

${ }_{39}$ Biel, Collectorium (supra, n. 30), dist. 15, quaest. 10, art. 3, dub. 3, p. 208: 'Accedit ad idem quod future contingentia sunt incerta et multis accidentibus possunt impediri. Ideo talis venditor non est certus, utrum supervenient quos putat superventuros.'

${ }^{40}$ Summenhart, De contractibus (supra, n. 33), tract. 3, quaest. 62, par. Tertius modus dicendi. 
All in all, then, Summenhart arrives more or less at the same practical conclusions as Aquinas or Biel despite the differences underlying their theoretical assessment of the 'Merchant of Rhodes'. It is worthy of mentioning, in this respect, that Summenhart spends long hours on developing an intermediary position that contains a lot of ideas on which the early modern scholastics would draw. According to this intermediary position, the "Merchant of Rhodes' actually subdivides into three categories.

In the first case, the seller needs to sell at the current market price without disclosing his information for the very reason that he cannot avoid proper damage without so doing. The buyer, for his part, is either buying for speculative reasons, or risks to incur a damage that is no greater in magnitude than the damage the seller seeks to avoid. In this event, the seller is under no obligation to share his information with the buyer for the simple reason that sound and sane charity begins with self-love (ordinata charitas incipit a seipsa) ${ }^{41}$. The second category concerns parties who both have a chance of benefiting from that contract even though the current market price is demanded, because the seller as well as the buyer are likely to be able to sell these goods in the future for the same or a higher price in the same or another place. In this case, the 'Merchant of Rhodes' can legitimately conceal his information because it is allowed to prefer his own gain to that of another person (licitum est mihi meipsum promovere, proximo neglecto $)^{42}$. Summenhart cannot approve, not even temporarily, of the third case, however. There, a seller is not going to incur any damage by disclosing his information, whereas a sale to the current market prices always is to the detriment of the buyer. This is a case of unjust enrichment, where the profit made by the vendor is directly based on the loss that falls on the buyer.

Significantly, in all three of the cases, Summenhart describes the relationship between seller and buyer in terms of a competition and contest (certamen). This view will reappear in the early modern scholastic tradition.

\section{3. - Early Modern Scholasticism}

\section{1.- Introductory remarks}

A number of seminal contributions written by legal historians on early modern scholasticism have seen the light in recent years ${ }^{43}$. It is to the credit

${ }^{41}$ Summenhart, De contractibus (supra, n. 33), tract. 3, quaest. 62, par. Secundus modus dicendi.

${ }^{42}$ Summenhart, De contractibus (supra, n. 33), tract. 3, quaest. 62, par. Secundus modus dicendi.

43 For references to recent contributions on scholastic legal thought, see W. Decock, Jesuit freedom of contract, Tijdschrift voor rechtsgeschiedenis, 77 (2009), p. 423-458. This article also contains a more detailed historical and philosophical contextualization of early modern scholastic legal thought. As to the philosophical context of early modern scholastic thought, a 
of the scholastics of the 16th and 17th centuries to have reached a fruitful synthesis of some of the most important intellectual traditions that previously prevailed in Europe. These range from Aristotelian-Thomistic natural law philosophy, Renaissance humanism, to the late Medieval ius commune. This synthesis was then passed on to prominent natural law jurists such as Hugo Grotius (1583-1645) and Samuel von Pufendorf (1632-1694).

The scholastic movement of the 16th and 17 th centuries is not of a purely theoretical nature, however, in spite of what recent publications often continue to suggest. No matter how influential and compelling some of their commentaries on 'On the laws' (De legibus), or 'On justice and law' (De iustitia et iure $)^{44}$, may prove to be to philosophers of law, early modern scholastic treatises are first and foremost the written imprints of very practical and dayto-day conflict management at a time when the Catholic Church, and its theologian-jurists in particular, still had a huge impact on real life decisions. If anything, the early modern scholastics acquainted themselves with the traditions mentioned above in order to find and forge adequate technical devices and tools to deal with the highly practical problems they were faced with as consultants to politicians and businessmen. It is well-known that they were heavily involved in finding solutions to the real-life questions that posed themselves in the wake of the discovery of the Americas. The status of the Indians, the relations between various nations, and the regulation of commercial activities on a globalized scale are but some of the pressing issues with which the Spanish empire was confronted, and the solutions for which they delegated to the theology faculty of the University of Salamanca amongst other centres of academic excellence on the Iberian peninsula.

The revived scholastic movement in the early modern period is also indicative of the Catholic Church's attempt to maintain its control over increasingly independent individuals and states. By giving consultancy to political authorities and to the business elite they hoped to consolidate their normative power in spite of the opposite tendencies ensuing from the Reformation and political absolutism. This search for normative power only increased after the Council of Trent. At the turn of the 17th century, we find the Jesuit order continuing and reinforcing the scholastic tradition which they inherited from the Dominicans, amongst other religious orders. With Jesuits like Luís de Molina and Leonardus Lessius we witness a growing juridification of the moral theological

fundamental contribution in an equally fundamental volume is M.W.F. Stone, Scrupulosity, probabilism, and conscience, The origins of the debate in early modern scholasticism, in: H. Braun / E. Vallance (eds.), Contexts of conscience in early modern Europe, 1500-1700, London 2004, p. 1-16 and p. 182-188.

44 These various types of literature stem from commentaries on different parts of Thomas Aquinas' Summa Theologiae, notably on IaIIae, q. 90-108 and IIaIIae, q. 57-80, respectively. Their autonomization is not only indicative of the growing importance of legal and moral affairs for the early modern scholastics, however, but also of the relative autonomy and independence of the latter authors with regard to Thomas's teachings. 
discourse. After all, they conceived of themselves as judges and jurists in what is to be understood literally as the court of conscience (forum conscientiae / forum internum). Through a meticulous analysis of both reality and legal theory, the Jesuits tried to find out which obligations and which rights belonged to an individual in very concrete circumstances as a matter of natural as well as positive law.

The outcome of a judgment in the court of conscience not only bore upon the confessant's soul, but also on his patrimonial rights and liabilities. Ever since Augustine (354-430) had said that no sin could be forgiven unless the balance which had been upset between people and their goods was restored, restitution had been at the core of the moral theological and canonical debate ${ }^{45}$. Still more symptomatic of the real impact in the external court (forum externum) of sentences pronounced in the court of conscience, are the legal remedies before the external courts that follow from them ${ }^{46}$. Against the background of the intense interconnectedness between the external and the internal court, it should not come as a surprise that the early modern scholastics constantly considered the duties to inform both from the perspective of the internal and the external court. Eventually, this exercise would even give rise to the birth of a new genre of comparative legal literature, namely Differentiae inter utrumque forum, iudiciale videlicet et conscientiae, as the Carthusian Juan de Valero (1550-1623) entitled his monograph.

\section{2. - Intrinsic defects}

During the first half of the sixteenth century, the Dominican theologians were by far the most famous and prolific members of the early modern scholastic movement that tried to re-think the Thomistic heritage in light of the emergence of the New World. One of the first Dominicans to lecture in Salamanca on the basis of Aquinas' Summa Theologiae was Francisco de Vitoria. After expounding the teachings of Aquinas, Vitoria treats of a doctrine not yet present in Aquinas's Summa Theologiae nor in the commentary of Tommaso de Vio (Cardinal Cajetan, 1469-1534) ${ }^{47}$, namely that when the buyer would not have bought the merchandise at all, had he known of the defect, he has entered into the contract involuntarily and, as a consequence, the contract is void ${ }^{48}$. Vitoria explains that this view is based on the teachings

\footnotetext{
45 See Augustine, Epistula 153, num. 20 [CSEL 44, III, 419]: 'Si enim res aliena, propter quam peccatum est, cum reddi possit, non redditur, non agitur poenitentia, sed fingitur: si autem veraciter agitur, non remittetur peccatum, nisi restituatur ablatum; sed, ut dixi, cum restitui potest'. This text was included by Gratian in C. 14 q. 6 c. 1.

46 See Joannes de Valero, Differentiae inter utrumque forum, iudiciale videlicet et conscientiae, Cartusiae Maioricarum 1616, praeludia [especially num. 4-5, and num. 15-16, p. 1-2].

47 The commentary of Cajetanus on the Summa Theologiae was edited together with the textcritical edition of Thomas's text in the Leonine edition (supra, n. 28).

${ }^{48}$ Franciscus de Vitoria, De Justitia (ed. V. Beltrán de Heredia), vol. 2, Madrid 1934; ad IIamIIae, quaest. 77, art. 3, p. 131-145.
} 
of Aristotle and that it was already defended in the Summa of Sylvester Mazzolini da Prierio (1456-1523 $)^{49}$. We have also encountered this idea, although less explicitly, in Summenhart's discussion of intrinsic defects. Vitoria himself, however, rejects this view by making reference to Cajetan. The involuntary element in the contract does not render it void, provided that the seller lowers the price in accordance with the defect, and that the defect poses no risks to the buyer. The chief basis for Vitoria's main argument is that a marriage entered into under false presumptions, is nevertheless valid. Granted, a contract entered into involuntarily can be inequitable, but only when one party is forced into it by the other party. In that case the contract is indeed void. Subsequently, Vitoria deals with the question, whether it is allowed to keep silent about defects, when selling at a just price, even where according to others the contract would be void in view of the fact that the buyer would not have bought at all, had he been aware of the defects.

There are three different opinions concerning this question. All three can be defended with reasonable arguments, but Vitoria himself prefers the third opinion. According to the first opinion, it is allowed to keep silent about a defect, as long as there exists no danger for the buyer and if the price is just. This opinion, which seems to be in conformity with the teachings of Aquinas, was rejected by the Scottish philosopher John Mair (Johannes Maior, 14691550) in his commentary on the Sentences of Peter Lombard. Mair considered such an act sinful ${ }^{50}$. Vitoria himself thinks that it is not allowed to deny defects when the buyer explicitly asks about their existence. Yet even though denying the existence of the defect is a sinful act, he still considers the sale contract to be valid. According to the second opinion it is better to inform the buyer when one of the features belonging to the natural condition of the object to be sold is lacking. A horse, for example, should not be lame. If the seller keeps silent about such latent defects, the buyer will be deceived and can claim rescission of the contract. If the defects are apparent, however, it is the buyer who should watch out. The third opinion consists in a middle course between the first two. The seller may keep silent about defects, when not explicitly questioned by the buyer. The main argument to support this opinion is that third parties (bystanders) do not need to interfere and have no duty to take care of the buyer's interest. They can also keep silent, although knowing that the buyer is about to buy something defective. If the seller conceals the defect upon explicit questions by the buyer, on the other hand, the contract may be rescinded and the buyer can claim damages.

49 Sylvester Prierias, Summa summarum, [Lugduni 1524], s.v. emptio, f. 213rb-213va, num. 20. Other writers also refer to Summenhart.

50 Johannes Maior, In quartum sententiarum quaestiones, Parisiis 1516, dist. 15, quaest. 40, f. $111 \mathrm{v}$. 
As stated above, this third opinion is the one preferred by Vitoria, albeit under the restriction that we are speaking here about defects in the quality, not about errors concerning the origin or age of the merchandise. It is striking to note that Vitoria emphasizes time and again that it does not pertain to the seller's duty to take care of the buyer's interest. Rather, he should act in his own interest, provided that he acts justly and without sinning. Aquinas had already stated that the seller is not obliged to disclose apparent defects. It was disputed, however, how this remark should be understood. Vitoria mentions the opinion of John Mair, for example, although eventually he does not seem to agree with his Scottish master. Following Antipater and criticizing Diogenes of Babylon, Mair holds that the seller is obliged to mention the defect, whenever it is not noticed by the buyer, irrespective of whether the defect is latent or apparent ${ }^{51}$. We should understand the scholars who state that an apparent defect does not have to be mentioned, as if they are referring to the situation the buyer had noticed it. In Mair's view, it is not fair for a seller to tell the buyer that the latter has a duty of enquiry (explora diligenter qualis sit) rather than he himself having a duty of disclosure. But Vitoria seems to disagree with this, and simply goes on to describe still other, legitimate interpretations of Aquinas's remark. One can say that Aquinas was talking about positive, human law, when he said that it is not necessary to mention an apparent defect, but that in the forum conscientiae the difference between latent and apparent defects is irrelevant. Or one can say that the buyer owes it to his own negligence (sibi imputetur), if he fails to notice an apparent defect.

In his commentary on article 3, the Dominican theologian Domingo de Soto treats the question concerning the seller's duty to disclose defects in the quality almost exclusively from the point of view of the forum conscientiae, leaving the forum externum explicitly to the jurists ${ }^{52}$. He first repeats the doctrine of Aquinas: the seller may keep silent as long as there is no danger and the price is just. Subsequently he states that this rule is in conformity with the opinion of the French theologian Jean Gerson (1363-1429) ${ }^{53}$. It is not in line with Summenhart's opinion, however, because the latter wants to increase the requirements for a non-duty of disclosure. Summenhart thinks that when the seller knows, or considers it to be likely that the buyer would not enter into the sale, if he knew the defects, he is under a duty to inform the buyer - an opinion which we have seen echoed in Mair a few decades later. Keeping silent in such a case would be unjust. This opinion of

\footnotetext{
51 Cf. Maior, In quartum (supra, n. 50) dist. 15, quaest. 40, f. 111v.

52 Dominicus Sotus, De iustitia et iure (with an introduction by V.D. Carro and a Spanish translation by M. González Ordóńez), Madrid 1968, lib. 6, quaest. 3, art. 2, p. 553-558.

53 Cf. Regulae Morales, n. 84, in: Jean Gerson, Oeuvres complètes (ed. P. Glorieux), vol. 9, Paris 1973 , p. 114-115.
} 
Summenhart's was also defended by the canonist Abbas Panormitanus ${ }^{54}$ and by Sylvester.

Soto himself returns to the original standpoint of Thomas Aquinas. Like Aquinas and Vitoria, Soto rejects the idea that an involuntary consent to the sale results in a void contract, at least when the buyer does not run a risk because of the defect, and the price is lowered. If Summenhart and his supporters are right, contracts would also be void in case of dolus incidens, but such an opinion they do not defend. Following Aquinas, Soto maintains that there is no duty to inform the buyer about patent defects. The seller may keep silent, as may any third party, because whoever exercises his own right does not do any injustice to his fellowman. All this seems to be in conformity with the ideas of Vitoria, but at this stage Soto introduces what appears to be a new and third requirement, in addition to those already mentioned in Aquinas (no injury and no risk for the buyer), namely the requirement of subjective utility (res sit emptori usui). The seller is only allowed to keep silent, when he does not realize that the defect makes the object sold unusable for the specific buyer he is contracting with. When selling a lame horse, the seller may conceal the defect for an old physician, who is looking for a calm animal, but not for a young nobleman who wants to participate in the horse races ${ }^{55}$. In case of patent defects, Soto remarks that there is no need to mention these and that the buyer, unless he is blind, may be presumed to enter knowingly into the contract. Soto does not seem to take into account the fact that the buyer may be inexperienced.

Vitoria and Soto reject the opinion that when the buyer would not have bought at all, had he known of the defects, the contract would be void. That opinion, which can be found in Panormitanus, Summenhart and Sylvester, was based on the distinction between dolus causam dans and dolus incidens, as well as on the Aristotelian idea that acts motivated by ignorance are involuntary. In the work of Juan de Medina, on the contrary, the legal distinction just mentioned appears to play a predominant role ${ }^{56}$. This is striking, since in the case of the 'Merchant of Rhodes', as we will see below, Medina also follows Summenhart closely. He writes that in the case of dolus dans causam contractui it is not sufficient merely to adapt the selling price in accordance with the defects, for the seller, in his capacity as salesman (ex

${ }^{4}$ See Abbas Panormitanus, Commentaria (supra, n. 31), ad X. 3, 19, 4, f. 141rb-va, n. 6. What Panormitanus actually says is that the seller has a duty to inform the buyer, if the latter is not careful (minus diligens) and is not watching very closely (et non bene prospexit).

55 This and similar examples can be found in other writers. In Domingo de Bánez (1528-1604) the young nobleman is a soldier who wants to go to battle. See Dominicus Báńez, Decisiones de iure et iustitia, Venetiis 1595, ad IIamIIae, quaest. 77, art. 3, p. 358. In Luís Lopez († 1596) one can sell a blind horse to someone who wants to use the animal for a treadmill. See Ludovicus Lopez, Tractatus de contractibus et negotiationibus, Lugduni 1593, lib. 1, cap. 45, p. 277.

56 Joannes de Medina, De poenitentia, restitutione et contractibus, Ingolstadii 1581 (reprint Farnborough 1967), tom. 2, quaest. 34, p. 211-214. 
officio), has the duty to inform the buyer. This rule should be observed not only when the seller knows for sure that the buyer would not buy if he knew of the defects, but also when he merely believes that to be likely. Otherwise, there will be culpa on the side of the seller. Just as in the theory of Soto, this leads to a third requirement, in addition to Aquinas' requirements that the buyer should not be caused injury nor risk: the seller should disclose the defect when he knows or considers it to be likely that the buyer would not enter into the contract should he be aware of the defect. Medina thinks it is only acceptable to keep silent about the defects, when the seller has no culpa in the dolus causam dans contractui of the buyer. According to Medina, his opinion does not deviate from those of Aquinas and Gerson, because both speak only of situations where there is no such culpa on the side of the seller. Subsequently, Medina deals with the situation of dolus incidens, i.e. when the buyer, if he knew of the defect, would nevertheless have bought the thing, albeit for a lower price. As a matter of fact, if the selling-price does not exceed the just price, there may still be dolus incidens, because this just price is not the price the buyer is willing to pay. According to Medina, in case of dolus incidens the contract is valid and there is no obligation to rescind it, unless that would be necessary in order to adjust the price ${ }^{57}$.

Again, this idea may be prompted by the fact that buyers are familiar with the market prices and can perceive a reduced price as a quality indicator. Nevertheless it may be sinful not to disclose the defect in such a situation. By not disclosing the defects, the seller compels the buyer, against the latter's will, to pay the just price, which is similar to seizing the debtor's goods in view of an unpaid debt. In order to demonstrate this, Medina produces some examples. I owe Peter 10 ducats and I am prepared to pay him that money. Peter, however, seizes my horse or other things I own worth 10 ducats. Or I owe Peter a horse valued at 10 ducats and Peter now takes possession of 10 of my ducats. Such behaviour certainly involves a sin, albeit not against the iustitia commutativa ${ }^{58}$. It is appropriate to note, however, that Medina indicates that all casuistry and rules are likely to have been established in view of contracts between professional tradesmen. He remarks that it is safer to deal with a wise and experienced party than with simple people (simplices). 'Safer' (tutior) means that in such professional trading there is a relatively small risk that there will be culpa on the side of one of the parties, resulting in a duty to make restitution. A similar view can be found in Francisco de Toledo (1534-1596), who teaches that a seller is not allowed to keep silent when the buyer is inexperienced or blind ${ }^{59}$.

\footnotetext{
57 Medina notices that this seems to contradict what Conradus stated in his second conclusion of question 54 .

58 Later writers, such as Pedro de Aragón presume that Medina is merely talking here about a sin against charity.

59 Franciscus Toletus, Summa casuum conscientiae absolutissima sive de instructione sacerdotum, Antverpiae 1623, lib. 8, cap. 49, p. 1145 , num. 2.
} 
Medina's opinion is for the greater part followed by the Augustinian friar Pedro de Aragón ${ }^{60}$. Aragón adopts the third requirement mentioned by Medina (no culpa on the part of the seller). He disagrees with Medina, however, on the topic of charity and duties to inform. In the footsteps of Bartolomeo Fumo $(\dagger 1555)^{61}$, Medina had argued that even though concealing defects does not always constitute a sin against justice, it can nevertheless be a sin against charity. Typically, however, Pedro de Aragón thinks that even concealing qualitative defects is not a sin against charity. Aragón rejects Medina's viewpoint because the latter had based his argument on an entirely inapplicable passage from the De officiis of St Ambrose that was quoted by Aquinas in the sed contra-argument in the above mentioned quaestio 77, article $3^{62}$. That reference is of no logical value, according to Aragón, since it refers only to cases where there is a risk of damage or danger, or in the event of dolus causam dans.

In addition, Aragón rejects the applicability of the example of compensation figuring in Medina. The one who seizures his debtor's ducats takes the law into his own hands, but does not deceive his fellowman, nor is he secretly receiving the latter's property. Apart from his stimulating discussion with Medina, Pedro de Aragón is one of the first to refine the rule that the seller is under no obligation to disclose the apparent defects. He does so by applying the notion of invincible ignorance (ignorantia invincibilis): ignorance that cannot be overcome. The distinction between invincible and non-invincible ignorance reaches back at least to Antonio de Córdoba, and it might constitute an important legacy of the early modern scholastics to legal thought ${ }^{63}$. Córdoba had defined ignorantia vincibilis as ignorance that can easily be overcome. Ignorantia invincibilis, on the other hand, cannot be overcome, however hard one tries and takes care (diligentia) in order to know what is unknown ${ }^{64}$. The seller should mention the defects when he notices that the buyer is suffering from inexperience (imperitia) or from such invincible ignorance. In the latter

${ }^{60}$ Petrus Aragonensis, In Secundam Secundae D. Thomae commentaria de iustitia et iure, Venetiis 1595, ad IIamIIae, quaest. 77, art. 3, p. 472-478.

${ }^{61}$ See Bartholomaeus Fumus, Summa aurea quae armilla nuncupatur, Antverpiae 1583, s.v. emptio, p. 271, num. 16.

${ }_{62}$ Thomas Aquinas, Summa Theologiae (ed. Leonina), IIaIIae, quaest. 77, art. 3, sc.: 'Sed contra est quod Ambrosius dicit, in III de Offic.: In contractibus vitia eorum quae veneunt prodi iubentur: ac nisi intimaverit venditor, quamvis in ius emptoris transierint, doli actione vacuantur'. 63 There possibly is a basis for the distinction between surmountable (non-excusable) and invincible (excusable) ignorance in Roman law, e.g. in D. 19,2,19,1, and the pair of ideas returns in 18th century authors like Augustin Leyser; see Zimmermann, The law of obligations (supra, n. 14), p. 367-368, and p. 869-870. It is arguable, however, that the first systematic and general application of the distinction between ignorantia invincibilis and ignorantia vincibilis stems from the scholastic tradition.

${ }^{64}$ See Antonius Cordubensis, Quaestionarium theologicum, Venetiis 1604, lib. 2, quaest. 1, p. 3-4. 
case the seller would commit a mortal sin if he were not to mention the defect. He would also turn out to be under a duty to make restitution, since he unjustly causes his fellowman injury. This clearly indicates that the general rules on duties to inform about intrinsic defects were formulated by the early modern scholastics against a background of professional merchants entering into a purchase-sale contract.

At the end of the sixteenth century, the leading role in the development of early modern scholastic legal thought is passed on from the Dominicans to the intellectual giants of the newly founded Jesuit order. One of the first Jesuits to become influential in moral and legal matters, is Gregorio de Valencia (1550-1603), who was born in Medina del Campo but eventually went to Dillingen and Ingolstadt as a theology professor. Concerning the question whether the seller may keep silent about the defects in the quality of the merchandise, he invents a unique and new dogmatic approach by introducing the concept of the 'conditional will' (velle conditionaliter) ${ }^{65}$. First he deals briefly with the situation in which the latent defect is in all respects going to frustrate the buyer's intention (intentio). In that event the seller is under a duty of disclosure. Then Valencia goes on to discuss more extensively the case in which the defect is not entirely incompatible with the buyer's intention. Under such circumstances what matters is that the buyer expresses his intention, namely that he communicates to the seller which defect he personally will not accept. It is this specific defect which matters to that particular buyer and which Valencia wants the buyer to express as an explicit condition. If he effectively does so, yet the defect in question still turns out to be present, the contract is to be rescinded at the request of the buyer (secundum voluntatem defraudati). Valencia makes clear that he is talking here about an explicit clause in the contract, resulting in merely conditional consent to the contract on the part of the buyer. Moreover, he argues that this is the situation Sylvester Prierias, Juan de Medina and Martín de Azpilcueta (1492$1586)^{66}$ had in mind when saying that in case of dolus causam dans contractui the sale is void. In Valencia's view, they had all envisaged conditional contracts, while our Jesuit interpreted Soto to have been talking about an unconditional sale when he pretended the sale based on dolus causam dans still to be valid. The reason why only an explicit condition concerning a specific defect can render the contract void when the defect is present, despite the buyer's expressly conditional consent, is supported through a simple, and pragmatic argument. Valencia holds that otherwise all contracts would be void. Hardly ever do we find a seller disclosing all defects. Very often, however, we do find a buyer who is somewhat disappointed upon receiving the merchandise. Yet

${ }^{65}$ See Gregorius de Valencia, Commentarii theologici, Ingolstadii 1595, tom. 3, disp. 5, quaest. 20 , punct. 4, cols. 1513-1525.

${ }^{66}$ See Martinus Azpilcueta (Dr. Navarrus), Enchiridion sive manuale confessariorum et poenitentium, Wirceburgi 1593, cap. 23, p. 672, num. 89. 
if this were to be sufficient reason to render a contract void, hardly any sales contract would remain safe from invalidity and unenforceability.

In sum, Valencia seems to add new requirements to Aquinas' rule that the seller may keep silent about the (latent) defects as long as they do not cause injury or danger. In Valencia's view, Aquinas' rule holds good unless the defects absolutely clash with the buyer's intention, or unless the buyer has consented to the contract under the express condition that a certain defect is absent. As regards patent defects, Valencia states that if the buyer does not notice the defect out of carelessness (incuria) - which amounts to noninvincible ignorance - what matters is whether the defect clashes with the buyer's intention, or whether it is incompatible with the explicit condition to his consent. Non-invincible ignorance does not grant the seller a right to compel performance from the buyer against his will. Hence, the words of Aquinas that patent defects do not have to be mentioned, should be interpreted as applying solely to cases where the seller clearly knows that the buyer had noticed the defect, but nevertheless wanted to buy.

Valencia's opinion did not become standard doctrine amongst the Jesuits. This may be due in no small part to Luís de Molina's contribution on duties to inform about intrinsic defects. A professor of philosophy at Coïmbra, who went on to teach theology at the University of Evora, Molina, more than anyone before him, discusses the civil law at great lengths ${ }^{67}$. It is within the context of his treatment of positive law, in particular, that Molina rejects the opinion that, when, according to the ius commune or Castilian law, an actio redhibitoria is granted, the contract is still valid in the forum externum. This opinion was derived from the argument that, if the contract was null and void, there would be no need to rescind it, and since a remedy was granted for this purpose, the contract was obviously valid. Molina, however, explains that this way of reasoning, which he ascribes to Summenhart, is not valid, because the actio redhibitoria can be used for other purposes and can also be used when the contract is already void. As the gloss Et eleganter ad D. 4,3,7pr. explains, the actio redhibitoria does not always serve to rescind an invalid contract, but also to restore the previous situation, thereby annulling the performances.

Valencia's criticism of the rule that even without an explicit condition concerning a specific defect the contract can be void when the defect is present, was endorsed by the Portuguese Jesuit Estevão Fagundez (1577-1645) ${ }^{68}$ and by Fernando de Castropalao $(1583-1633)^{69}$. They agreed that, if this were

${ }^{67}$ The civil law is at the centre of attention in Ludovicus Molina, De iustitia et iure, tom. 2, Conchae 1597, disp. 353, cols. 598-615.

${ }_{68}$ Stephanus Fagundez, De iustitia et contractibus et de acquisitione et translatione dominii, Lugduni 1641, lib. 5, cap. 38, p. 483.

69 Ferdinandus de Castropalao, Opus morale de virtutibus et vitiis contrariis, Lugduni 1700, part. 7 , tract. 33 , disp. 5 , punct. 22 , p. 366, num. 4 . 
to be followed, hardly any contract of sale would be valid and all social and commercial life would be disrupted. As Vitoria already said 'no mule is born without a spot' (no nace mula sin tacha). Molina also must have appreciated this undesirable effect, but the solution he offers is entirely different to Valencia's theory of conditional consent. Molina returns in the footsteps of Soto. With Soto he rejects the idea that dolus dans causam contractui makes the contract involuntary and thus void for the simple reason that this should also be said for cases of dolus incidens. If the buyer would not have bought had he known of the defect, it was reasoned that his consent is involuntary and his ignorance makes the contract void. But whoever accepts this, should also accept that, if the buyer would have bought the thing but not for the present price, his consent is similarly involuntary and his ignorance would likewise make the contract void. The latter view, however, was never defended by the scholars Soto and Molina were challenging.

Moreover, Molina also adopts a utility requirement, albeit an objective one, and not a subjective one as was the case with Soto. This is Molina's first important contribution to the discussion on duties to inform about intrinsic defects. A second innovation is that Molina considers only major defects to be relevant, thereby referring to Roman law (D. 21,1,1,8 and D. 21,1,4) and to the gloss Mala enfermedad ad Siete Partidas 5,5,65. So we can say that as a principal rule in Molina's doctrine the seller is allowed to conceal the defects, if they do not cause injury or risk (Aquinas), and as long as they do not lead to a considerably reduced utility for the purpose for which the merchandise is usually sold. This criterion was to become influential, not only in Early Modern scholasticism, but also in the schools of natural law in the North of Europe. As a consequence, whether we sell the lame horse to an old physician or to a young nobleman is of no relevance. In Molina and his followers we find plenty of examples making clear which defects do, and which defects do not make a certain thing considerably less useful from an objective point of view. For instance, the one who sells a slave who is not inclined to run away and has no serious diseases, is not obliged to tell the buyer that the slave is one who takes it easy or likes to drink wine ${ }^{70}$. For that slave is not particularly useless according to objective standards of usefulness. Similarly, a cobbler is not obliged to tell the buyer that the shoes he made are not made out of the best quality leather. This is different when the defect makes the merchandise considerably less useful from an objective point of view. In such a case the seller should not only adapt the price, but also tell the buyer why he did so. Examples of defects which make the merchandise considerably less useful in an objective sense are salted meat and fish which are sold on the market as

70 According to other writers, addiction to drink is a quality which does make the slave considerably less usable. See Castropalao, Opus morale (supra, n. 69), tract. 33, disp. 5, punct. 22 , p. 366, num. 8 . 
though they were fresh and without preservatives, because, generally speaking, a buyer wants that kind of food for immediate consumption ${ }^{71}$.

As regards patent defects, according to Molina there is no remedy available in the forum externum, unless an action is based on laesio enormis. In the forum conscientiae no remedy lies at all as long as the sale is equitable, and except for cases where at the moment of entering into the contract, it was absolutely clear to the seller that the buyer did not realize that there was a considerable, albeit patent, defect in the merchandise. If the defect renders the object considerably less useful for its (objective) purpose, the seller is under a duty of conscience to warn the buyer.

The criterion that the (objective) utility of the merchandise should not be considerably reduced by the defects, appears to have become the prevailing idea. We find it in the writings of many other Jesuits, for example Leonardus Lessius, a Jesuit born near Antwerp - then the major port and metropolis of northern Europe - who taught moral theology at the Jesuit College in Louvain, and is well-known for his in-depth knowledge and familiarity with contemporary business practice ${ }^{72}$. Referring himself to the usual practices and customs in trade relationships (consuetudo mercatorum), Lessius too states that the mere fact that the buyer would not have bought the goods, had he been aware of the defect, does not make the sale void in an absolute sense and does not result in an obligation to make restitution. A seller is allowed to conceal the defects in his merchandise - provided, of course, that the buyer is not likely to run the risk of incurring damage or danger, and that the defects do not make the object considerably less useful for the purpose required (ad usum cui expetitur). Whether the latter points in the direction of a subjective or an objective utility requirement, however, is not entirely clear. Moreover, when the buyer examines the merchandise and is going by his own judgement and does not ask anything except the price, the seller's only obligation is to see that the selling price is just. He has no obligation to disclose latent defects. It even suffices to show the buyer the risk of danger after the sale is concluded. If the buyer's expectations are frustrated subsequent to such a deal, he only

${ }^{71}$ See Joannes de Lugo, Disputationes de iustitia et iure, Lugduni 1646, tom. 2, disp. 26, sect. 8, p. 334, num. 134; Antonius Escobar y Mendoza (1589-1669), Theologia moralis, Lugduni 1659, tract. 3, exam. 6, cap. 3, p. 400-401, num. 30, and cap. 5, p. 407, num. 69; and Ferdinandus de Castropalao, Opus morale (supra, n. 69), tract. 33, disp. 5, punct. 22, p. 367, num. 12.

${ }^{72}$ Leonardus Lessius, De iustitia et iure, Antverpiae 1621, lib. 2, cap. 21, dub. 11, p. 284-286. In a student's notes of Lessius's lectures De iustitia et iure copied by Philippus Rovenius, whose manuscript is preserved in the Utrecht University Library (Hs 6 G 7), the question of intrinsic defects is dealt with in cap. 10, dub. 4, f. 92r-93r. There is some controversy about the authorship of the manuscript, cf. T. Van Houdt, Leonardus Lessius over lening, intrest en woeker, 'De iustitia et iure', lib. 2, cap. 20, editie, vertaling en commentaar, [Verhandelingen van de Koninklijke Academie voor Wetenschappen, Letteren, en Schone Kunsten van België, 162], Brussel 1998 , p. XV. 
has to blame himself for not having asked the seller's advice (si deceptus est, sibi imputet).

Lessius realizes that such a rule might be at variance with the Roman law provisions of D. 19,1,13 and D. 21,1,1 which grant a remedy for rescission if the seller did not disclose the defects. But he does not consider that to be a problem. For one thing, the Roman rule is merely derived from positive law. It is only in force where it is received by custom, for another. The Roman rules could also be interpreted as applying to cases where the buyer had expressly asked the seller to disclose the defects, or in the sense that rescission is only granted by judicial decree. According to natural law, then, which is the ultimate criterion in the court of conscience, a seller is under no obligation to disclose latent defects unless the buyer expressly asks him to do so ${ }^{73}$. The seller who does not inform a buyer relying on his own judgement, may act against the virtue of charity, however, when he sees that the buyer is erring because of his simplicity (simplicitas), and not merely because of lack of prudence and diligence (levitas). In this respect, even the criterion of objective utility needs some modification, in the sense that a seller needs to inform a buyer suffering from simplicity when he knows that the object will be useless for this poor man's specific purposes, although the object might still be useful to others despite its defects.

The Jesuit Juan de Lugo seems to have followed into the footsteps of Lessius, by introducing the distinction whether or not the buyer indicates to the seller for which purpose he wants to buy ${ }^{74}$. No doubt this is merely a more explicit account of the dichotomy present in Lessius. If a buyer does not indicate his subjective purpose regarding the thing sold, the seller is allowed to conceal the defects when they do not make the merchandise considerably less useful for the purpose for which the object is normally sold. If this is not the case, however, the seller is tacitly deceiving the buyer and merely adjusting the price to the defective quality will not be sufficient. If the defect in itself is patent, there is no need to mention it, unless the specific buyer is so blind or ignorant (rudis), that he does not see what is visible to others. In such a case, the patent defect must be presumed to be latent. According to Fernando de Castropalao the seller should disclose patent defects, whenever it is clear that the buyer is not capable of recognizing these because of his lack of expertise or his rustic simplicity (rusticitas). However, the latter should not be too readily presumed, because even country dwellers and peasants are careful to inspect the things they buy. In the court of conscience, however, it is better to disclose even the patent defects as if they were entirely latent in such a

${ }^{73}$ Leonardus Lessius, De iustitia (supra, n. 72), lib. 2, cap. 17, dub. 5, p. 201, num. 33 (in fine).

${ }^{74}$ Joannes de Lugo, De iustitia (supra, n. 71), disp. 26, sect. 8, p. 332-338. 
case, because from the position of the buyer (comparatione emptoris) they actually are latent ${ }^{75}$.

\section{3. - Extrinsic defects}

Known for his vital role in the renaissance of Thomism at the University of Salamanca, it should not come as a surprise that we find Francisco de Vitoria follow the view of Thomas Aquinas in his commentary on the Secunda Secundae ${ }^{76}$. Yet at the same time he strengthened the arguments underlying it, contrary to Cajetan, who had failed to elaborate on the 'Merchant of Rhodes' in his own commentary on Aquinas 77 .

Vitoria distinguishes between a merchant's simply keeping silent (tacere) about future market conditions, and his making positive statements about the future that are not in line with his own information (decipere). Only the latter act is formally speaking a positive act of deceit from bad faith (deceptio positiva mala fide) and therefore a sin that obliges the 'Merchant of Rhodes' to make restitution. Keeping silent, on the other hand, is not considered a sin by Vitoria at all. For a businessman is not expected to put his own interests at risk (agere rem suam) by behaving 'like a teacher'. The ultimate criterion then is the current market price, determined by public information. Vitoria points out the absurdities that would ensue from taking into account private information as a price determining factor. Under that assumption, a businessman with more information about the future would be worse off than a businessman who had less information, since the latter could still demand the current market price.

Conversely, Vitoria also approves of buyers who make a deal at the current price in spite of their knowledge about future scarcity. To support his view, he refers to the anecdote about Thales the Milesian, told by Aristotle in his Politics $^{78}$. Eager to show that philosophers can easily get rich if they like, even though their ambition is of another sort, Thales hired all the olive-presses in winter because he knew by virtue of his astronomical predictions that there would be a great harvest of olives in the coming year. In summer, naturally, he made a substantive profit. An excellent story, showing that speculative activities based on a dominant knowledge position were approved. What is more, he thought speculation to be an essential part of commerce and business acumen (est ars mea quod scio esse sic futurum), which everybody has a right

75 Ferdinandus de Castropalao, Opus morale (supra, n. 69), part. 7, tract. 33, disp. 5, punct. 22, p. 366, num. 7 .

${ }_{76}$ See Francisco de Vitoria, In IIamIIae (ed. B. de Heredía, supra, n. 48), quaest. 77, art. 3, ad 4, p. 144, num. 16.

77 Cajetanus, In IIamIIae (ed. Leonina, supra, n. 28), quaest. 77, art. 3, ad 4, p. 153.

78 Aristoteles, Politica, 1, 11, 1259a5-1259a23. We consulted the following edition: Aristotelis Politica, recognovit brevique adnotatione critica instruxit W.D. Ross, [Scriptorum classicorum bibliotheca Oxoniensis], Oxonii $1973^{5}$ [= 1957], p. 20-21. 
to practise, provided blatant fraud and deceit are absent. Therefore, Vitoria could not argue that the 'Merchant of Rhodes' had a duty of disclosure about extrinsic 'defects'.

In his De iustitia et iure, Domingo de Soto continued the Dominican view bequeathed to him by his master Vitoria. He simply held that a merchant is under no obligation to disclose his information about future market conditions ${ }^{79}$. His somewhat dull and short discussion of the 'Merchant of Rhodes', which repeats Aquinas' argument, and merely contains references to the story of Joseph in Genesis and Aristotle's account in the Politics of Thales the Milesian's speculative activities, stands in marked contrast to the vivacity of the debate as it appears in one of Vitoria's teachers at the University of Paris. During his stay there from 1508 till 1522, Vitoria not only got involved in the renaissance of Thomism. Next to his contacts with Pieter Crockaert (ca. 1450-1514), the Dominican friar from Brussels who had reintroduced Aquinas' Summa theologiae as a textbook at the theology faculty of Paris, Vitoria also studied with one of the foremost nominalist thinkers of the time, the Scotsman John Mair. In point of fact, there is no doubt that Vitoria drew heavily on the latter's intense and compelling discussion of the 'Merchant of Rhodes' ${ }^{80}$.

John Mair restructures the case in terms of a grain merchant from Normandy who arrives in London at a time of great dearth - knowing that other ships are on their way - or in terms of a wine merchant from Burgundy who wants to speculate on higher prices in the Paris region. What is more, John Mair fully recognizes a merchant's right to demand the current market price without telling anything about the future market conditions. This, however, only holds true within the boundaries of the professional market. Anticipating an important qualification to the 'Merchant of Rhodes', later to be adopted in no small a degree by the Jesuits, Mair expressly holds that when confronted with a simple and non-professional buyer (simplex forum ignorans), the merchant has a duty of disclosure. Still, in the wake of Konrad Summenhart, whom he explicitly quotes, Mair thinks of the relationship between professional market participants as a contest (certamen).

Interestingly, Mair approves of the three cases which Summenhart had carefully put forward but rejected in expounding the intermediary position. He declares that no matter whether the seller needs to sell at the current market price in order to be able to make profits or merely to avoid his own damage, the damage the buyer incurs on account of this never constitutes a form of unjust enrichment. If the 'Merchant of Rhodes' does not disclose his information in order to avoid his own damage, he is not liable for the buyer's damage, because it is allowed for him to prefer the avoidance of his own detriment (potius se servabit indemnem quam alios). He can even pursue a clearly profitable bargain that is to the detriment of the buyer, because a

79 Sotus, De iustitia et iure (supra, n. 52), lib. 6, quaest. 3, par. Ad tertium, p. 557-558.

${ }^{80}$ Cf. Johannes Maior, In quartum (supra, n. 50), dist. 15, quaest. 41, f. $113 \mathrm{v}-114 \mathrm{r}$. 
merchant has a right to capitalize on an opportunity that is present and certain rather than to wait for a likely, but nevertheless uncertain chance to make money in the future. To fail to do so would be a testimony to the "Merchant of Rhodes" lack of economic prudence (essem imprudens relinquere mihi lucrum praesens). Mair also defends this view on the grounds that the "Merchant of Rhodes' has a duty to look after the well-being not only of himself but of his entire family (oportet me mibi et familiae meae providere). Therefore he cannot afford to let slip an opportunity to make money on the basis of his dominant knowledge position.

Domingo de Soto's relatively tedious discussion is all the more perplexing given that only a few years before he wrote his treatise, the whole debate about the 'Merchant of Rhodes' had been reinvigorated and turned topsyturvy by Juan de Medina.

Unrestrained by fidelity to the official line taken by a religious order, say the Dominicans, Medina answers the question of the 'Merchant of Rhodes' in the negative ${ }^{81}$. A merchant is not allowed to sell at the current price when he knows that the price is going to fall in the near future. Since he knows that the common estimation of the current price stems from false assumptions and a lack of information (ex errore seu ignorantia), he cannot in good faith decide to demand a price based on it. Like Summenhart, Medina thinks that the current price is not the just price but merely a fictitious price (pretium putatum) that does not correspond to its real value. In addition, he repeats Summenhart's claim that a not too distant arrival of a large supply of a commodity has the same price-lowering effect on the common estimation as if it were effectively present. Buyers consenting to the high current price are only doing so from a lack of knowledge, i.e. they are not consenting voluntarily (non libere consentiunt in pretii quantitate). According to Medina, a seller is obliged to inform the buyer of his personal knowledge of future changes in both the intrinsic and extrinsic qualities of a commodity. Otherwise he commits a sin against charity, particularly if the buyer enters into the agreement with a view of stock-piling (ad servandum eas) rather than consuming immediately.

Medina maintains that for a contract to be allowed, not only should there be a fair ratio of money to commodities, guaranteed by the just price, but also a balanced relation between buyer and seller: their conditions should be equal (debet ipsorum contrahentium conditio aequalis esse) - and he clearly thought that the level of information was part of that personal condition. Like the Stoic philosopher Antipater, he infers this from the distinctly social function of contracts which should be of use to the common good of all market participants (pro communi contrahentium utilitate sint institutae). Hence, the question whether an individual seller sells in good faith or in bad faith is of singular interest, with Medina considering the 'Merchant of Rhodes'

${ }^{81}$ Cf. Johannes de Medina, De poenitentia (supra, n. 56), tom. 2, quaest. 35, p. 214-217. 
to be guilty of deceit. Nevertheless, he concludes, with Summenhart, that the 'Merchant of Rhodes' is not obliged to demand the fully decreased future price. It suffices for him to lower the price just a little bit in accordance with his knowledge, or to disclose his information to the buyer.

From this conclusion Medina derives the solution to four cases he evoked in the course of his discussion, and which will remain a constant point of reference in the subsequent treatments of the 'Merchant of Rhodes': (1) A merchant who knows that a city in which his goods are stocked is going to be besieged, is not allowed to sell his stock promptly at the current market price; (2) A landlord knowing that the royal court is going to move away from the region where he holds his estate, can no longer rent his house to an ignorant tenant at the current price; (3) Someone who has insider information about a future statute or decree that will lower the price of grain, is not allowed to sell his stocks at the current price; (4) Someone having insider information about a future devaluation cannot change his money at the current exchange rate. It is worth noting that, certainly in the third case, Medina could have supported his solution by making a reference to Bartolus de Saxoferrato, but this he did not do.

A fundamental contribution to the question of good faith and deceit to which Medina had paid so much importance is to be found in the Relectio in regulam Peccatum of the canonist Diego de Covarruvias y Leyva. Covarruvias introduces what he calls the beautiful question (pulchra dubitatio) of speculation, and the 'Merchant of Rhodes' in particular, into the debate about deceit in card playing agreements ${ }^{82}$. Significantly as we shall see below, the Jesuit Leonardus Lessius transferred Covarruvias's image of the card playing contract into the case of the 'Merchant of Rhodes'.

What makes Covarruvias' contribution so compelling is his notion that fraud and deceit can only be measured when compared with what he literally calls the laws of the game (leges ludi). He holds, indeed, that every game is ruled by its own natural laws on which all parties entering into such a game tacitly agree. All measures of prudent deceit and precaution (dolus et cautelae) that are in accordance with the laws of the game cannot give rise to a complaint. In case of doubt as to whether the limits to these acts of prudence and carefully applied deceit have been transgressed, the advice of experienced and knowledgeable men (iudicium peritorum) is the ultimate criterion of judgement. Under reference to the distinction in D. 4,3,1,3 between bad deceit (dolus malus) and good deceit (dolus bonus) - good deceit being synonymous with skill (sollertia) - Covarruvias explicitly conceives of dolus bonus as an essential part of the natural laws of a gaming contract. He again affirms, by inserting rather dubious references to the Ordinary Gloss to D. 19,5,5,2,

82 Cf. Diego de Covarruvias y Leyva, In regulam Peccatum, de regulis iuris, lib. 6, Relectio, part.

2, par. 4, in: Opera omnia, Augustae Taurinorum 1594, tom. 2, p. 486-488. 
D. $19,5,17,2$, D. $45,1,85$ and D. $50,17,161$, that it is always allowed to avail yourself of the laws of the game.

Subsequently, Covarruvias addresses the question whether it is allowed for a card player to raise stakes on seeing that he has a good hand. Some say it is not. In this respect, he quotes Bartolus de Saxoferrato's and Ludovicus Pontanus Romanus' condemnation of a seller who avails himself of his insider information to make profits. In addition, he quotes Conradus' and Medina's appeal to the 'Merchant of Rhodes' to disclose his information about future market circumstances. But then he goes on to make the case for the opposite view. A card player is not obliged to share his information with the other parties to the contract, on account of a natural law of gaming ( ob naturalem ludi legem) which implies that somebody who has a good hand is allowed to take advantage by raising his stakes. Conversely, a player who finds himself with a bad hand, has a right to try and deceive his challenger by bluffing and raising the stakes. Covarruvias quotes the commentator Philippus Decius $(1464-1536)^{83}$, and Juan de Medina in support of his view. Medina had argued, indeed, that card players implicitly agree to the law of gaming contracts, namely that a player who has a fortunate hand can raise his stakes ${ }^{84}$.

As Covarruvias points out, a parallel between the case of card playing and the 'Merchant of Rhodes' is actually difficult to establish, because the nature of the purchase-sale contract is different from a game. Hence Bartolus' objection is irrelevant. What is more, by referring to Aquinas, Covarruvias holds that Bartolus' assessment of the 'Merchant of Rhodes' is entirely false. He asserts that, with the exception of a civil servant, a seller who enjoys a dominant knowledge position does not have a duty of disclosure, although he would clearly prove to be richer in virtue, if he shared his information.

In the subtitle to his Quaestionarium theologicum, Antonio de Córdoba explicitly mentions his aim to solve cases of conscience on the basis of both the legal and the theological tradition. Córdoba is one of the rare theologians, indeed, who mentions the commentators Bartolus de Saxoferrato and Ludovicus Pontanus Romanus as proponents of Summenhart's and Medina's unconventional position within the scholastic tradition. Córdoba intends to reconcile the two separate traditions which had developed in addressing the position of the 'Merchant of Rhodes'. One of the few Franciscan friars who played a fundamental and influential role in moral theological and legal debates in the early modern period, he thus produced an extensive account of both positions before the final re-working of the case by the Jesuits took place at the turn of the $17^{\text {th }}$ century.

${ }^{83}$ Decius actually approved of a betting contract in favour of a certain Silvester in which another person promised him to give a certain amount of money if condition $\mathrm{x}$, which Silvester knew with certainty to happen, would be fulfilled; cf. Responsa sive consilia, Francoforti ad Moenum 1588, cons. 115.

${ }^{84}$ Johannes de Medina, De poenitentia (supra, n. 56), tom. 2, quaest. 22, p. 151. 
Although Córdoba proposes a third way in order to mediate between the two positions, one might wonder if it represents anything more than an attempt of a pupil to pay respect to his reverend master Juan de Medina ${ }^{85}$. His third way consists of a distinction between cases where an ordinary market price exists already, and cases were such a price is lacking. In the former the opinion of Aquinas and his followers should be followed, whereas Medina is to be taken as a guide in the event that no established market price or official price, determined by the public authorities, exists. A somewhat theoretical distinction, one might say. It certainly is, if one considers that Córdoba actually brings the argument of the Thomistic tradition to perfection, while refuting Medina's standpoint indirectly in representing it as a possible objection to the Thomistic point of view.

Córdoba holds that Medina's concern about good faith and the absence of deceit is not actually incompatible with the Thomistic argument. In explaining why, he expressly points out the crucial distinction between circumstances that are extrinsically or intrinsically relevant to the formation of a just price. According to Córdoba, Medina is right in looking to good faith, but only to the extent that the knowledge of a particular party to the contract concerns circumstances that intrinsically contribute to the establishment of a just price (cognitio et ignorantia conditionum intrinsece et per se facientium ad iustitiam pretii rerum constituendam ${ }^{86}$. An example of such a circumstance is a defect in the thing sold as to its natural value, substance, quality or quantity. The Thomists are right, however, in not having regard for this so-called good faith in conditions where the knowledge of it is definitely to be considered extrinsic and accidental for establishing a just price (cognitio et ignorantia conditionum extrinsece et per accidens facientis ad iustum pretium constituendum). Examples of such circumstances are future market conditions such as abundance and scarcity. Hence, Córdoba does not believe the 'Merchant of Rhodes' to be under a duty to disclose his information. Neither does he believe that anyone in the four cases addressed by Medina is bound to do so, though he hesitates in case of the landlord.

The contrived and purely theoretical nature of Córdoba's intermediary position is highlighted by the Augustinian Pedro de Aragón in his De iustitia et iure $^{87}$. For if the just price is not yet determined by common estimation or the public authorities, in practice this will mean that the object of sale is

85 In his Quaestionarium (supra, n. 64), lib. 1, quaest. 14, par. Opinio prima, p. 135, he calls him 'clarissimus doctor Medina magister meus'. Compare A. Lamela, Aportación bio-bibliográfica en torno a Fray Antonio de Córdoba, O.F.M. (1485-1578), Liceo francescano, 6 (1953), p. 179208.

${ }^{86}$ Antonius Cordubensis (Antonio de Córdoba), Quaestionarium (supra, n. 65), lib. 1, quaest. 14, p. 136 .

${ }_{87}$ Petrus Aragonensis, In secundam secundae (supra, n. 60), ad quaest. 77, art. 2 et 3, p. 635637. 
a luxury. But the price of such goods is established individually by agreement between the seller and the buyer (ex contrahentium conventione), and the seller can try and get the best bargain he can for such goods, even by keeping silent about their future abundance in the market.

With Aragón, the general theory of just pricing becomes increasingly involved in the process of finding the right solution to the 'Merchant of Rhodes'. Aragón is eager to both underpin the Thomistic point of view and to rebuke Medina by referring to the theory of just pricing. A seller can sell at the current market price without disclosing any information about the future, since the true and just value of things is not determined by the estimation of one single person (iustus et verus valor rerum non ex privata unius vel duorum pendet aestimatione), but by common estimation of the price. In turn the common estimation or the official price are not dependent on the knowledge or ignorance of an individual, but on the knowledge of the community. Aristotle himself had pointed out in the fifth book of the Nichomachean Ethics, as Aragón rightly affirms, that justice complies with objective and not with subjective criteria (est iustitia a parte rei).

Against Medina, Aragón repeats Córdoba's distinction between intrinsic and extrinsic circumstances which determine the just price, and he repeats the thesis that the just price is dependent solely on the common, public knowledge or ignorance (per solam communem cognitionem vel ignorantiam). Furthermore, Aragón holds that the 'Merchant of Rhodes' is allowed not only to keep silent about what he knows (tacere), but even to make false statements and to lie (mentiri) if the buyer asks him about his knowledge. $\mathrm{He}$ argues that this is just a white lie (mendacium officiosum), which a seller has a right to use in order to avoid a significant loss himself. The consequent damage incurred by the buyer is merely an accidental consequence (per accidens damnificetur) of the seller's right to protect his own resources. Thus regarded as a matter of the virtue of justice, which merely looks at the balance between rights and obligations, nothing is wrong, with this purchase-sale contract. Aragón draws a parallel here with two beggars that are equally poor: both of them have a right to lie to one another with regard to the presence of an almsgiver, because they are equally entitled to obtain those alms (uterque pauper habet idem ius).

Yet by insisting on looking at the 'Merchant of Rhodes' from the perspective of justice, Aragón at the same time triggers the question as to how the case of the 'Merchant of Rhodes' is to be assessed, then, in terms of the greater virtue of charity. Here again, his reasoning is astonishingly liberal. Reminiscent of Summenhart and Mair is his claim that sound and sane charity takes its origins in self-love (charitas bene ordinata a seipso incipiat). Hence, a merchant only has a duty to take care of his neighbour if that is not to his own detriment. For example, if the 'Merchant of Rhodes' does not expect himself to be particularly worse off without making the deal at the current price, while the 
buyer would suffer very serious damage, he has a duty either to disclose his knowledge about the future to that buyer, or to look for two or more buyers in order to make more deals of a minor importance (divisim) instead of selling his whole supply to this one buyer who is going to be ruined. If, however, not concealing his own information, or not making expressly false statements about his true knowledge would be to his own, grave detriment, Aragón concludes that, even as a matter of charity, it is not wrong for the 'Merchant of Rhodes' to refrain from disclosing the right information from the other party to the contract.

To sum up, through emphasizing the theory of just pricing, in opening the discussion about lying, and by defending the 'Merchant of Rhodes' even as a matter of charity, Aragón anticipates the discussion by the Jesuits Luís de Molina, Leonardus Lessius, and Juan de Lugo.

The Jesuit tradition is not as uniform as a quick glance at the 'big three' just mentioned might lead one to suspect. This has already appeared above as regards the duty to disclose intrinsic defects. In his Commentarii theologici Gregorio de Valencia - whose thought seems as sophisticated in legal affairs as that of his pupil Suárez in matters metaphysical - develops a unique argument ${ }^{88}$. To be sure, he took sides with the Thomistic tradition, and produced a convincing rebuttal of Medina's views, yet at the same time his resolution of the cases put forward by Medina was more in line with its original author's spirit than that of mainstream early modern scholastic thought.

On a theoretical level, Valencia succeeded in proving the absurdity of Medina's insistence on applying the bona fides requirement to the knowledge of future market circumstances. A standard argumentum ex absurdo against Medina's position, reaching back at least to Córdoba, had been that if a seller with knowledge of a future fall in prices who had not disclosed his information or reduced the contractual price was under an obligation to make restitution, then a seller who had not known about the future decrease in the price level at all would also be held liable to make restitution of the difference between the current market price and the future market price. For the just price imposed itself upon everybody invariably.

Now Valencia tries to imagine how Medina could have replied to this critique. He could have said that the buyers would not have been particularly irritated by the latter seller, and accordingly would have considered their own consent to his offer voluntary. In addition, in Medina's analysis, this seller's good faith would have discharged him from the obligation to make restitution (bona fides illum ab obligatione restituendi liberaret). Yet this is nonsense, says Valencia, since the requirement of justice in economic exchange depends on

${ }^{88}$ See Gregorius de Valencia, Commentarii (supra, n. 65), tom. 3, disp. 5, quaest. 20, punct.

4, p. 1462-1465. 
the balance between price and object regardless of the intentions and attitudes of the persons involved. Put in a more legal terminology, the obligations ensuing from justice follow the object (obligatio sequitur rem). If the future price were already the just price, then that would affect all transactions involving the current, high market price, even of sellers acting in 'good faith'. Logically speaking, every seller charging the current price should be under an obligation to make restitution on account of the fact that he holds a surplus with regard to the just proportion between the object and its new (decreased) price. But this is an absurd conclusion, accordingly proving the absurdity of Medina's point of departure.

Nevertheless, Gregorio de Valencia proves himself to be not wholly insensitive to Medina's fallible logic in addressing the cases assimilated to the 'Merchant of Rhodes'. By way of example, take the case of the merchant who is eager to sell his stocks at the current price because he knows about the coming siege of the city where his commercial activities are centred. Here Valencia applies Medina's distinction between a buyer entering into the contract in order to consume the goods immediately himself, or one intending to stock them and sell them to other merchants in the future. Valencia believes that in the latter case, the grain merchant is held to make restitution because of the damage the purchaser incurs. Juan de Lugo will later criticize his older colleague for having taken this viewpoint, no doubt because it is difficult to square with the speculative activities regularly going on in professional markets.

With Luís de Molina, Leonardus Lessius, and Juan de Lugo we enter the heydays of Jesuit legal and moral thought as transmitted to us in their treatises De iustitia et iure ${ }^{89}$. Although two issues were to become predominant in their reflections on the 'Merchant of Rhodes', namely lying, and insider trading, their highly developed casuistry about the pre-contractual duties to inform about future market conditions is not identical.

For example, in the wake of Aragón they share a common commitment to a consistent application of the theory of just pricing in the case of the 'Merchant of Rhodes', repeating time and again that individual knowledge is irrelevant as to the common estimation which ultimately determines justice in contractual affairs. But Lessius' express insistence on the fact that it is not significant that the common estimation is based on mistake and ignorance (etiamsi ista aestimatio ex errore vel ignorantia procedat), is certainly remarkable $^{90}$. Lugo's claim that there is no information problem in the 'Merchant of Rhodes' because of the extrinsic nature of future market circumstances (vitium est extrinsecum) is in line with the teachings of Córdoba, Lessius, or Molina, but the tenacity with which Lugo insists, from the outset, on the

${ }^{89}$ Ludovicus Molina, De iustitia (supra, n. 67), tom. 2, disp. 354, cols. 616-622, Leonardus Lessius, De iustitia (supra, n. 72), lib. 2, cap. 21, dub. 5, p. 278-280, Johannes de Lugo, De iustitia (supra, n. 71), tom. 2, disp. 26, sect. 8, p. 332-338.

${ }^{0}$ See Leonardus Lessius, De iustitia (supra, n. 72), lib. 2, cap. 21, dubit. 10, p. 284, num. 180. 
non-obligation of disclosure of knowledge about future scarcity or abundance, and his consistent distinction between intrinsic and extrinsic circumstances to a contract, is exclusive. Lugo is also much more avid to enter into a discussion with his predecessors than Lessius or Molina, who mainly limit their criticism to Medina. He again picks up Córdoba's question of the relevance of private information about future market conditions in the event that no price is established and argues that public authorities are under an obligation to disclose their private knowledge about future abundance or scarcity in establishing the price of a new commodity, or in re-establishing the price of an old. For civil servants, judges, and princes have a duty to nurture common welfare through all means and information at their disposal.

This brings us to the issue of insider trading, which we have seen underlying Bartolus de Saxoferrato's discussion of the 'Merchant of Rhodes'.

The issue is likely to have gained increasing interest among the Jesuits for the merely practical reason that they themselves got deeply involved in public administration as private counsellors and confessors. To Molina, Lessius, and Lugo, the question is whether a merchant who has obtained precious information about a change in the regulations concerning, for example, the grain market, could speculate on that information, by selling more grain (plus) than he had originally intended at the current high price.

Molina soundly condemned a merchant who speculated on such insider information. Claiming support from the Portuguese jurist Aries Pinellus ${ }^{91}$, who taught at Coïmbra and Salamanca, Molina drew a distinction between information that should be imparted to all members of the community, on the one hand, and information which an individual is allowed to possess privately, on the other. Moreover, a decree or law is a typical example of knowledge that should be known by the whole community (lex publica aequalis ac communis esse debet subditis omnibus), and, therefore, should not be a source of personal enrichment. Of course, if the merchant refrains from speculating on his insider information, and simply sells the goods he initially intended

91 Aries Pinellus, De rescindenda venditione, cum annotationibus Emanuelis Soarez, Rinthelii 1667, part. 3, cap. 2, num. 22-24, p. 418-419. Pinellus mentions that Fulgosius disagreed with Bartolus's condemnation of a merchant making profits on the basis of insider information. Fulgosius argued, according to Pinellus, that a contracting party should be allowed to use his careful cleverness (astutia et diligentia) to his own advantage. Pinellus, however, thinks it is safer to follow the common opinion based on Bartolus. What is more, Pinellus thinks that in the court of conscience, as opposed to the forum externum, the 'Merchant of Rhodes' is never allowed to make profits on the basis of his dominant knowledge position, even if knowledge does not concern the enactment of a future decree. He expressly defends Cicero's view. Molina clearly has no legitimate claim to authoritative support from Pinellus, then. For scant biographical details on Pinellus, whose work is full of references to the humanist jurists, as well as to the early modern theologians and commentators in the Bartolist tradition, see V. Herrero Mediavilla (ed.), Indice biográfico de España, Portugal e Iberoamérica, 4th edition, vol. 8, München 2007, p. 4122, s.v. Pinello, Arias. 
to bring onto the market, he can safely demand the current price. For he should not suffer damage by knowing of the future enactment before the rest of the community. Consequently, in Molina's opinion, the conclusions concerning the 'Merchant of Rhodes' cannot be applied without qualification to the case of insider trading. In speculating, the 'Merchant of Rhodes' does not appropriate to himself knowledge of a fact which should be commonly known. Rather, his profit-making is based on his industry, business acumen, and good luck (spectat ad industriam, artem atque eventum fortunae).

Contrary to Molina, however, Lessius and Lugo hold that taking advantage of insider information about a future decree is allowed, even if it is to the detriment of other citizens. They simply ignore the distinction drawn by Molina between different types of knowledge. Lessius states that, contrary to a civil servant, a citizen is not expected nor under an obligation to promote the benefit of others. Crucially, he now transfers the laws of gaming, highlighted and defended by Covarruvias, to the purchase-sale contract - a telling move which reveals Lessius' all permeating idea of business as a game ${ }^{92}$. Since it is allowed for a card player to raise stakes on seeing that he has a good hand, by the same token, a businessman should be allowed to sell a surplus when fortune smiles upon him. Moreover, Lessius argues in a most liberal vein, that there is no law forbidding the 'Merchant of Rhodes' to avail himself of his insider information about a future enactment. Hence he is allowed to speculate on it.

Juan de Lugo even goes a step further. He believes that civil servants or public authorities can themselves take advantage of their insider information about a future change in the regulations. For even though decrees should be to the advantage of all, knowledge of them prior to their promulgation can be used for private purposes. What is more, instead of abuse of power, Lugo considers these speculative activities by the administration itself as pertaining to economic prudence (est actus prudentiae oeconomicae). He merely forbids civil servants to try and obstruct the promulgation of the decree (ex industria differre legis promulgationem) in order to extend the period in which they can benefit of their private knowledge.

Similar differences in considering pre-contractual duties to inform about extrinsic circumstances are to be found in the three Jesuits' respective assessment of lying.

Molina is careful to stress that using lies, deceit, and fraud is strictly forbidden. His opinion is succinct, clear and does not even admit of a brief consideration about the issue of white lies. In solving the four specific cases mentioned by Medina, Molina affirms time and again that a seller can exercise his right by selling at the current price (iure suo uti), precisely on the condition that lies and fraud are absent (sine mendaciis et aliis fraudibus). Lessius, on

92 Leonardus Lessius, De iustitia (supra, n. 72), lib. 2, cap. 21, dubit. 5, p. 279, num. 46-47. 
the other hand, repeats Aragón's point of view that the 'Merchant of Rhodes' can lawfully make false statements both as a matter of justice and charity in order to protect his self-interest when either he or the buyer is going to suffer damages because of a future decrease in price.

Lugo is of the same opinion as Lessius, although his argument becomes a little more sophisticated ${ }^{93}$. He distinguishes between two situations. In the first, a buyer makes explicit enquiries into the seller's knowledge. Still, a seller has a right not to disclose his information, according to Lugo (utitur iure suo nolendo manifestare quod scit). He can simply make use of mental reservation (aequivocatio), telling to the buyer that he does not know anything about the future, while adding in his mind that he does not know anything that is publicly known. Lugo points out that this is how he interprets Lessius' statements. The second situation Lugo envisages concerns a seller who makes radically false statements, or even positively contributes to the spreading of distinctly false information about the future market conditions. In that event, the agreement is null in favour of the buyer on account of deceit causing the contract (dolus causam dans).

\section{4. - Reception in the Protestant natural law tradition}

\section{1. - Intrinsic defects}

As is generally acknowledged, the writings of the early modern scholastics have left their traces in the works of Hugo de Groot (Grotius, 1583-1645). This certainly holds good for the paragraphs in the Inleidinge tot de Hollandsche rechtsgeleerdheid where Grotius is dealing with liability for latent defects ${ }^{94}$. It seems that Grotius applies two separate sets of rules. First he uses the distinction between dolus causam dans contractui ('is dat ghebreck zulcks dat waerschijnelick de koop daerom zoude zijn achterghebleven') and dolus incidens ('zoo de koop waarschijnelick even-wel voort-gang zoude hebben gehad'). In the first case the sale can be rescinded, in the second the buyer can claim reduction of the selling price. Subsequently, Grotius raises an objective utility requirement, closely resembling that of Molina and his followers. Grotius speaks about a defect which makes the merchandise less useful for its usual purpose ('indien 't gebreck zodanig is dat de zaeke daer door tot haer gewoonelicke ghebruick onbequamer is'). There is, however, a minor difference between this formula and the one in Molina, namely that in Grotius' text it is not stated that the defect should not render the merchandise considerably less useful. Moreover, although the influence of Molina's utility concept is clearly present, Grotius

93 Johannes de Lugo, De iustitia (supra, n. 71), tom. 2, disp. 26, sect. 8, p. 337, num. 145.

${ }_{94}$ See Hugo Grotius, Inleidinge tot de Hollandsche rechts-geleerdheid, III.15.7 (ed. F. Dovring, H.F.W.D. Fischer, E.M. Meijers, Leiden 1965, p. 245-246). 
is probably talking here about the situation where the seller himself is not aware of the defects. This appears from the last lines of Grotius' fragment, where he states that if the seller, apart from what is stated before, knew the defects at the time the sale was concluded, he is beyond doubt liable for all damages, including consequential losses. In the early modern scholastics, however, the central question - should the seller disclose the defects? presupposes that the seller is aware of these defects. Anyhow, when the defect renders the object less useful for its usual purpose (and the seller was not aware of the defect), the buyer has, according to Grotius, the choice between claiming rescission of the contract and price reduction. This is entirely in conformity with the Roman law provisions where the seller is in good faith. The same can be said for the features of the remedy for price reduction, as described by Grotius. It has to be brought within one year like the Roman law aedilitian actio quanti minoris, which in the Gloss is termed as actio quanti minoris pretoria. As concerns the other Roman law remedy for the same purpose, namely the actio empti, which in the Gloss is termed as actio quanti minoris civilis ${ }^{95}$, it had been disputed whether it was annual in duration or perpetual. Grotius does not mention the remedy by its Roman name, but in his day the prevailing opinion was probably that the civil actio empti, when used for price reduction, prescribes in one year. Moreover, the assessment of price reduction can, according to Grotius, be achieved in two ways: it is either the shortfall between the selling price and what the buyer would have paid if he had known the defect ('zulckes deels des koopsgelds, als hy de zaeck minder zoude hebben ghekocht') or the shortfall between selling price and market value ('zulcks deels als de zaeck inder daed minder waerdig was'). The first method of assessment, taking the pretium singulare as starting point, Grotius derived from the actio empti ${ }^{96}$, the second way, taking the pretium commune as starting point, from the aedilitian actio quanti minoris ${ }^{97}$. As one can notice, Grotius was building on various authoritative traditions. Early modern scholasticism was certainly one of those, but not the only one.

Samuel von Pufendorf (1632-1694), who from 1661 until 1686 was teaching at the University of Heidelberg, also dealt with questions related to defective merchandise. Unlike Grotius, however, the influence of early modern scholastic concepts is less clear. It is mainly the principle of just pricing which appears to be a determinative factor. First Pufendorf points out that the one who by means of a contract is about to transfer an object to another, is obliged not only to indicate the qualities but also the defects of his merchandise, namely as far as he is familiar with these. Otherwise it would not be possible

\footnotetext{
95 See the gloss Essem empturus ad D. 19,1,13pr.

${ }^{96}$ See D. 19,1,13pr.: '(...) quanti minoris empturus esset, si ... scisset (...)'; and C. 4,49,9: '(...) quanto, si scisset emptor ab initio, minus daret pretii (...)'.

${ }^{97}$ See D. 21,1,38: '(...) quo minoris cum venirent fuerint (...)'; and D. 21,1,31,5: '(...) quanti minoris is homo sit (...)'.
} 
to determine the just price. This rule is, subsequently, substantiated by quotations from Cicero, St Ambrose, Lactantius (ca. 250-320) and Plato (ca. 428-347 BC) ${ }^{98}$. Further, it is stated that this obligation follows from the nature of the act itself, not from positive law ${ }^{99}$. Moreover, it is of no importance to indicate defects which are known to the buyer. Both parties have in this respect an equal position. This is also true in case of defects which the seller has shown to the buyer: then the buyer no longer has a reason to ask for rescission of the contract ${ }^{100}$.

\section{2. - Extrinsic defects}

Hugo Grotius and Samuel von Pufendorf both touched upon the 'Merchant of Rhodes'101.

Explicitly referring himself to the early modern scholastics and the Medieval legal tradition, Grotius made a distinction in his De iure belli ac pacis between pre-contractual duties to inform about defects in the merchandise on the one hand and knowledge about external circumstances on the other - a distinction later adopted by Pufendorf too. Continuing the 'rights-talk' of the early modern scholastics, he did not think it to be necessary, according to the principles of justice, that a seller communicates his knowledge in the latter case. For not communicating his knowledge infringes no-ones right. Unfortunately, Grotius only briefly suggests that the behaviour of the 'Merchant of Rhodes' often goes against the rule of charity, but does not clarify his statement. It might seem that Grotius would have taken a tougher stand on this than the early modern scholastics in the tradition from Aragón till Lugo.

Pufendorf, on the other hand, clearly takes a position as to the charity point of view. Typical of the trend towards secularization in Pufendorf s work is the re-appearance of the concept of 'charity' in the form of 'the law of beneficence and humanity' (lex beneficentiae et humanitatis). According to Pufendorf, there are three main reasons denying, from the point of view of the law of humanity, that the 'Merchant of Rhodes' is obliged to disclose his knowledge. First, in order for an obligation to arise from the law of humanity, it is necessary that another person is really in need of beneficence. Now the latter is obviously not the case with the purchasers in the 'Merchant of Rhodes', because from Antiquity the inhabitants of Rhodes were renowned for their wealth. So although they might be in need of grain, they certainly were not

98 Samuel Pufendorf, De jure naturae et gentium, part 2, lib. 5, cap. 3, par. 2, p. 467-468 (ed.

F. Böhling), Berlin 1998.

99 Pufendorf, ibid., par. 3, p. 468-469.

100 Pufendorf, ibid., par. 5, p. 470.

101 See Hugo Grotius, De jure belli ac pacis libri tres, lib. 2, cap. 12, par. 9 (ed. B.J.A. De Kanter - Van Hettinga Tromp; annot. R. Feenstra et C.E. Persenaire), Aalen 1993, p. 344-345, and Samuel Pufendorf, De jure naturae et gentium (supra, n. 98), lib. 5, cap. 3, par. 4, p. 469. 
in need of money or any other beneficence. Secondly, Pufendorf holds that a duty of beneficence cannot arise if by telling the truth one incurs expenses which exceed the benefit accruing to the other party. Now if the 'Merchant of Rhodes' discloses his information, the loss in profits he suffers will exceed the increase in gain for a plurality of buyers. His third and last argument recalls Lessius' sharply drawn distinction between the logic of the market and the logic of gift: usual business practice does not aim to be beneficent.

Grotius and Pufendorf do not take the controversial view of some early modern scholastics that making false statements or lying is permitted both as a matter of justice and charity for the 'Merchant of Rhodes' to avoid a loss.

\section{5. - Conclusion}

Responding to the widely attested emphasis across European jurisdictions on the present day duty to inform, this paper set out to clarify a decisive historical period in the formulation of the problem of the legal relevance or insignificance of certain information disparities between contracting parties: that is early modern scholasticism. Significantly, early modern theologians and jurists came to apply in a consistent manner the distinction between two types of defect, namely those intrinsic and those extrinsic to the purchase-sale contract. We have seen a good example of this dichotomy in the writings of the Franciscan Antonio de Córdoba. On the one hand, there are intrinsic conditions that are constitutive for the just price. On the other, there are circumstances to a contract that determine a just price extrinsically and by extraneous circumstance.

Contrary to extrinsic defects, duties to inform about intrinsic defects still determine the agenda of present day contract doctrine. If the volume edited by Sefton-Green is indicative, this is true of present day Europe more than ever before. It may be contrary to all expectations to find that the early modern scholastics, mostly moral theologians by education, put less emphasis on the duty to inform about intrinsic qualities of the merchandise than we do nowadays. In their debates on intrinsic defects, they judge the necessity of the duty to inform by surprisingly liberal standards. Generally speaking, they are not prepared to demand that a seller always spontaneously discloses the known intrinsic defects in his merchandise, an omission which according to Roman law results in full contractual liability. This becomes more apparent as the sixteenth century progresses.

The starting point was Aquinas' short statement that latent defects should be mentioned when they could cause damages or risk of danger. Hardly any scholar ventured to interpret this rule in an a contrario way, i.e. by stating that whenever there was no chance of damages or danger, the seller was free to deceive the buyer. All late scholastic writers appear to agree that the rule as phrased by Aquinas was too simplistic to be applied directly and that a 
refinement of the statement, consisting in one or more further conditions, was appropriate. In so doing they borrowed concepts from the civilian tradition, although they never adopted the Roman law principle that any malicious conduct on the part of the seller results in liability. The initial approach which, building on both ius commune and Aristotelian ideas, considered that dolus dans causam contractui made the buyer's consent involuntary and, as a consequence, the contract void, soon gave way to a new criterion, not derived from Roman law.

Soto added the criterion that the defect should not render the object sold unusable for the specific needs of the particular buyer entering into the contract. This subjective utility criterion was developed into an objective utility requirement by Molina. He stated that the seller is under a duty of disclosure if the defect is likely to render the object sold unusable for its normal and ordinary purpose. Almost immediately, however, this rule was restrictively interpreted. Indeed the seller had to mention latent defects, but not minor defects, as stated by Molina himself, and not when the buyer was relying on his own judgement, as taught by Lessius. At the same time it became increasingly apparent in the Jesuit writers of the late sixteenth century and the beginning of the seventeenth century that the context of their teachings is a market with professional or at least equally strong parties.

It is not in the least because of their increasing recognition of the professionalism of the market and the autonomous rules of the business game that the early modern scholastics definitively considered that extrinsic defects did not constitute knowledge that should be disclosed. They did so in their commentaries on the case of the 'Merchant of Rhodes', which, through Thomas Aquinas and Saint Ambrose, they borrowed from Cicero. Except for the dissident voices of Summenhart and Medina, the early modern scholastics generally acknowledged that a seller could take advantage of his knowledge about future market circumstances without having to disclose about them to the buyer. Significantly, we saw Lessius applying Covarruvias' image of the implicit rules of good deceit and speculation in gaming contracts to ordinary purchase-sale transactions.

Special cases that gained increasing interest with the Jesuits Molina, Lessius, and Lugo concerned the questions of insider trading and lying when the seller was asked by the buyer to disclose information about future market conditions. Although Bartolus de Saxoferrato had expressed serious doubts about an insider taking advantage of knowledge about the enactment of a future decree, the Jesuits gradually took a more realistic stand by allowing that to a certain extent businessmen made profits through learning from contacts in the administration about changes in statutory law concerning the market.

To sum up, then, by relying on their market insight and on rational arguments, the early modern scholastics succeeded in transforming what was still thought to be a troubling question, originally raised by the famous rhetorician 
and jurist Cicero, into a simple fact: information about future market circumstances is one of the basic profit-making instruments of an industrious businessman. Therefore, a seller cannot possibly be expected to be under a duty to communicate that kind of knowledge to his rival, to employ Mair's telling metaphor of business as a contest. It is small wonder, then, to find that once the problem had been settled for good by the scholastics, the problematic character of the question of the duty to inform about extrinsic defects seems to have largely disappeared from the horizon of later jurists like Pufendorf and Savigny.

Generally speaking, the moral-juridical debates of the early modern scholastics are clearly pervaded by the maxim, expressed for the first time in eighteenth century treatises on Anglo-American law, and frequently suggested to have its origin in Roman law ${ }^{102}$, namely that a buyer should be cautious (caveat emptor $)^{103}$. Time and again they proclaim that it is not the seller's duty to take care of the well-being of the buyer and that he is entitled to secure his own interests.

Thus we are facing a paradoxical situation. On the one hand, positive jurists at the beginning of the 21 st century witness a kind of re-moralization of contract law, in the sense that the observance of comparatively lofty standards seems to be demanded from sellers knowing about defects in their merchandise. On the other hand, moral theologians and scholastics of the $16^{\text {th }}$ and $17^{\text {th }}$ centuries seem to have reduced the duty to inform to a strict minimum that is nowadays associated with the civilian tradition and thin morality.

The explanations of this liberal turn in early modern scholastic legal and moral discourse are manifold ${ }^{104}$, but two points need emphasizing here.

First of all, the early modern scholastics focussed on what a seller was obliged to do in conscience. Positive law only provided some of the concepts applied in this area and was used for comparison. But this does not mean that early modern scholastic moral thought had lost touch with real life or that it had to do with vague moral theory and with lofty dreaming about a better world. Due to their daily activity as consultants to businessmen and politicians, the $16^{\text {th }}$ and $17^{\text {th }}$ century moral theologians were very much engaged in practice, while their idea of 'conscience' was of a concrete, realistic, and legal nature. For them to know what a man was bound to do in conscience, was to observe the virtues of Aristotelian-Thomistic philosophy, albeit often shaped in concepts derived from Roman, canon, and statutory law, to the real life facts at hand.

102 See, for example, J.A. Crook, Law and life of Rome, London 1970, p. 181.

${ }_{103} \mathrm{H}$. Broom, A selection of legal maxims classified and illustrated, Philadelphia 1882 (reprint Union, 2000), p. 768-809.

${ }^{104}$ For a more extensive analysis, see W. Decock, Lessius and the breakdown of the Scholastic paradigm, Journal of the History of Economic Thought, 31 (2009), p. 57-78 (esp. p. 69-75). 
Secondly, these scholars and practitioners knew where to draw the line between the sphere of justice in exchange and the sphere of charitable love. As a basic rule they imposed in conscience on the seller an even more restricted duty to inform than required by positive law, namely the mere observance of the equality-principle of Aristotle's commutative justice. In principle it is only this standard, which by no means can be characterized as a lofty or vague criterion, which has to be observed. Only when these prudent businessmen had left the professional market and were dealing with non-professionals, definitely if these were considered particularly poor or weak, assertive commercial behaviour and 'rights-talk' had to make place for charitable empathy. 